\title{
A Methodological application of New Techniques for Rationalization Energy Consumption in Buildings
}

\author{
${ }^{1}$ Eng. Sayed Marey Mansour, ${ }^{2}$ Prof. Randa Reda Kamel, ${ }^{3}$ Dr. Inas Abd-Elsabour Ahmed* \\ 1,2,3 Helwan University, Faculty of Engineering, Architecture Department
}

\begin{abstract}
Sources of energy are the most important challenges facing the world in this century. The global interest in energy and its relation to the construction sector that consider the most energy consuming sectors, which led to a search for methods of energy conservation. Research assumes a methodology to apply the modern technology in buildings and gaining advantages of developed building materials, outer envelopes, and conserve energy systems to reduce energy waste and increase its efficiency by integrating natural and renewable energy applications. This methodology could be applied to buildings during the design phase to achieve energy rationalization.
\end{abstract}

Keywords Energy rationalization, Modern techniques, Renewable energy, Building life cycle

\section{Introduction}

Energy sources are one of the most important challenges facing the world in this century, which greatly affects the national economy and postpone the movement development. Accordingly, studies have shown that the construction sector is one of the most energy-consuming sectors in the world. Besides, it consumes about $40 \%$ of the world's total energy, and about $68 \%$ of the total consumed electricity [1]. Most of this energy is produced from non-renewable sources, that warning the world countries to think about new energy sources, and explore other various resources to reduce their consumption, or move towards construction methods that preserve energy and look for raising energy efficiency during the building life cycle.

\subsection{Research Problem}

Developed countries concerned with sustainable architecture and energy rationalization in all types of buildings during their life cycle, by basing on the precautions, regulation, requirements and energy codes. While in developing countries, including Egypt, buildings were often designed and implemented without taking into consideration the effect of building materials and outer envelopes on energy efficiency. This due to either the lack of construction regulation

\footnotetext{
* Corresponding author: Assistant Professor at Faculty of Engineering, Helwan University e-mail: inas.abdelsabour@m-eng.helwan.edu.eg
} 
requirements or the limited availability of techniques for buildings' design and implementation in a manner that conserves and rationalizes energy.

Therefore, the research problem arises due to the absence of a process that governs how to earn the advantages of both developed building material techniques and outer envelope systems, to clarify their role in achieving the building energy efficiency, to use it in rationalization methods of energy consumption during building life cycle starting from the design phase until recycling phase.

The proposed methodology utilizes modern techniques in various building elements to help in rationalizing energy consumption in buildings and increase their efficiency. The application of this methodology on buildings during the design stage, which effects also on the other building stages from implementation to demolition.

\subsection{Research Aims}

The research aims to find a methodology to utilize modern techniques in the building, either from the external elements, outer envelope systems or internal building systems, for using in rationalizing energy consumption and upgrading the building's efficiency. This can be achieved by a number of objectives as follows:

- Explain ways to conserve non-renewable energy sources, and how using strategies to raise energy efficiency in buildings.

- Defining the energy status in Egypt and the impact of the construction sector on consumption.

- Classification of using modern technologies to rationalize energy in buildings.

- Determining the modern technologies' impact on buildings during the design stage and verify its effect on building life cycle.

\subsection{Research Methodology}

For achieving the purpose of this work, the research adopts two steps; theoretical and analytical study:

- First, Theoretical study: via studying the energy in buildings; by defining its sources, applications and the categories of rational consumption. Moreover, identifying the usage of modern technologies to rationalize energy consumption in buildings, through clarifying its applications in all building elements, (external elements-internal elements-the outer envelope).

- Second, Analytical study: Developing a methodology for rationalizing energy consumption methods in buildings by using modern techniques through analyzing some case studies that applied these techniques.

\section{Energy in Buildings}

\subsection{Energy Resources:}

There were many energy types surrounding us, most of them were converted to electric or kinetic energy, that could be classified into either non-renewable energy or renewable energy: 


\subsubsection{Non-renewable energy sources:}

This kind requires a long time to develop, like (petroleum, coal, gas), it also considered one of the main causes of environmental pollution and global warming.

\subsubsection{Renewable energy sources:}

It is generated by a natural continuous source (wind, water, sun, hydrogen power, geothermal energy). Egypt had several resources in the renewable energy field and aims to increase the ratio of generating renewable energies to $20 \%$ of the total energy capacity by 2020. The energies that used in Egypt, are [2]:

Hydropower energy; It is produced from High Dam power station and Aswan reservoir, with production average $13350 \mathrm{GW} / \mathrm{H}$, Fig. 1 [3].

Solar energy; Egypt is one of the solar belt countries, and suitable for solar energy applications with a brightness rate 9:11 h/day. The vertical sunbeam average is $2000 / 3200 \mathrm{~kW} / \mathrm{H}$, but until 2011 the output rate of solar energy electric power does not exceed $206 \mathrm{MW} / \mathrm{H}$ at the Elkorimat station in Giza, however by completing the implementation of Kom Ombo project the rate will be $100 \mathrm{MW} / \mathrm{h}$ rate, Table 1 [3].

Wind Energy; There are many suitable areas in Egypt for producing wind energy. Consequently, the production has increased from $140 \mathrm{MW} / \mathrm{H}$ in 2005 to 545 $\mathrm{MW} / \mathrm{H}$ in 2011, Table 1 [3].

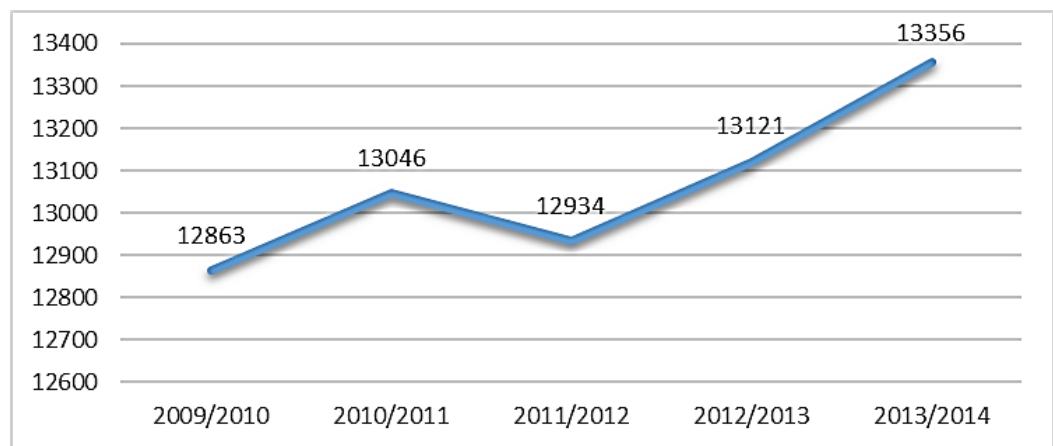

Figure 1 The development of electric production from hydropower in Egypt [3]

Table 1 The development of solar and wind production in Egypt [3]

\begin{tabular}{|l|l|l|l|l|l|l|l} 
Report/year & $\mathbf{2 0 0 5}$ & $\mathbf{2 0 0 6}$ & $\mathbf{2 0 0 7}$ & $\mathbf{2 0 0 8}$ & $\mathbf{2 0 0 9}$ & $\mathbf{2 0 1 0}$ & $\mathbf{2 0 1 1}$ \\
\hline Total efficacy (MW) & 18775 & 20452 & 21944 & 22583 & 21330 & 22750 & 23470 \\
\hline Zafarana winds & 140 & 225 & 225 & 300 & 425 & 517 & 545 \\
\hline Ghergada winds & 5 & 5 & 5 & 5 & 5 & 5 & 5 \\
\hline Solar thermal station & - & - & - & - & - & - & 140 \\
\hline Energy production $(\mathbf{G W} / \mathbf{H})$ & 101229 & 108690 & 100708 & 108788 & 131063 & 139000 & 141885 \\
\hline Zafarana winds & 523 & 552 & 627 & 840 & 941 & 1152 & 1489 \\
\hline Ghergada winds & 9.6 & 9 & 8.3 & 7 & 7 & 7 & 7 \\
\hline Elkoraimat solar station & - & - & - & - & - & - & 206 \\
\hline
\end{tabular}

\subsection{Renewable Energy Applications:}

\subsubsection{Solar Energy}

Solar energy is generated by thermal motors or photovoltaic transformers. Thus, they were either negative or positive solar systems, in accordance with the way of utilization, conversion and distribution. So, solar energy systems can be classified into two main types, as in Table 2 [4,5]: 
Table 2 Solar energy devices $[4,5]$

\begin{tabular}{|c|c|c|c|}
\hline \multicolumn{2}{|c|}{ Solar Energy } & Concept & Example \\
\hline \multirow{3}{*}{ 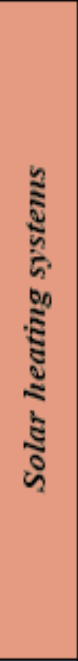 } & 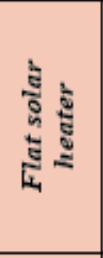 & $\begin{array}{l}\text { It is a metal insulated box with a glass or transparent plastic } \\
\text { cover, with an inside sheet from copper or aluminum or alloy } \\
\text { from both (often in black) for best heat absorbing, then water or } \\
\text { air flew in the inner pipes to be heated. As a result, hot water is } \\
\text { stored inside heat-insulated tanks, which could be from glass or } \\
\text { fiberglass to keep the water's heat, especially during night. }\end{array}$ & \\
\hline & 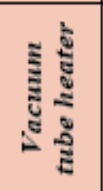 & $\begin{array}{l}\text { the sun penetrates the glass surface and reach the closed } \\
\text { paralleled transparent vacuumed glass tubes to absorb heat, } \\
\text { then by contact the water was heated and stored in a tank. }\end{array}$ & \\
\hline & 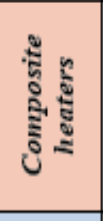 & $\begin{array}{l}\text { This type uses convex mirrors that rotated with the sun } \\
\text { direction, to reflect the concentrated sun rays in a collecting } \\
\text { point above the absorbent sheet. Then, water pass through to be } \\
\text { heated with higher temperatures more than with normal solar } \\
\text { heaters. }\end{array}$ & \\
\hline \multirow{3}{*}{ 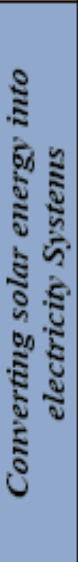 } & 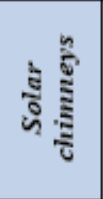 & $\begin{array}{l}\text { It depends on the solar radiation, that warms air at the station's } \\
\text { bottom and rises up due to the air's low density (caused by the } \\
\text { huge temperature difference). Then air permits in the chimney } \\
\text { turbines to generate electricity. }\end{array}$ & \\
\hline & हैं & $\begin{array}{l}\text { It relies on the sun's concentration on an oil filled tube, then } \\
\text { the temperature rises and the oil flows on a water heat } \\
\text { exchanger then heated and evaporated. As a result, the turbines } \\
\text { spin due to this steam to generate electricity. }\end{array}$ & \\
\hline & 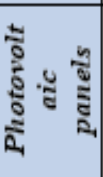 & $\begin{array}{l}\text { it generates the electric power by assembling of solar modules } \\
\text { "PVs" in an integrated system for the electric power } \\
\text { conversion. }\end{array}$ & \\
\hline
\end{tabular}

\subsubsection{Wind power}

Wind turbines are widely used to produce electric power, such as windmills for mechanical energy, and wind pumps for water pumping. Moreover, 95\% of the used land as wind fields can be used for agriculture or grazing, and it could be also placed above buildings. Conversely, its disadvantages, is the visual effect of turbines' rotation and noise, so it was preferred to be located in isolated areas, Fig. 4 [6].

\subsubsection{Hydropower Energy}

When water flows through levels, it rotates the turbines that move the generators. The electric power can also be generated by using the natural tidal movement near the shoreline, where special turbines were placed in the tidal stream operated by rising and falling of water, then the water returns and runs again [6].

\subsubsection{Biomass Energy}

Bioenergy is one of the most renewable energies that can be used to provide clean and usable energy for residential buildings, especially in rural and non-urban areas, which are produced from renewable organic substance origin from plant and animal [7]. 

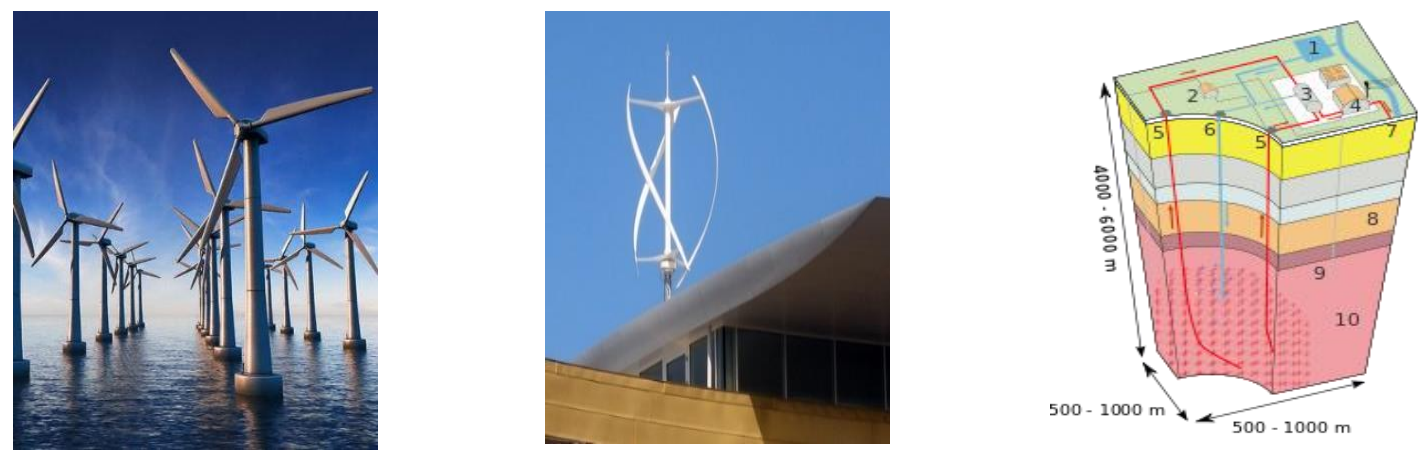

Figure 4 Wind power horizontal and vertical axis [6] Figure 5 Geothermal Energy [6]

\subsubsection{Geothermal Energy}

Underground heat is a clean, environmentally friendly energy, that characterized by low cost after calculating the initial costs of station's production. In opposition, it requires large areas and hard to dig deep wells with depths up to $5 \mathrm{~km}$ at high temperatures, Fig. 5 [6].

\subsection{Energy charge rates in buildings}

Buildings are the largest consumer of energy, with an $40 \%$ average of the consumed energy. America is considered one of the largest energy consumers, then Europe and the Gulf countries. In addition, the consumption rate of the Egyptian individual in 2007 is $(1384 \mathrm{~kW} / \mathrm{h})$, and the global rate is $(4,190 \mathrm{~kW} / \mathrm{h})$, which is less than one-third of the world average. So Egypt was ranked the $85^{\text {th }}$ from world consumption of electricity [2]. Fig. 6 displays energy consumption in Egypt, according to activity. Consequently, when designing a building, it is necessary to take into account the total consumed energy through building phases, from construction to repair or even the case of removal and restoration. The building's energy needs vary in each stage of its life cycle, that depends on the building's supply of the required energy, so these needs depend on a number of factors:

- Location, climatic and natural conditions.

- Access easily to energy sources.

- Variable usage of technologies and systems and its cost.

- Changing the building's installation and construction methods.

- Nature of building maintenance, its components, and services.

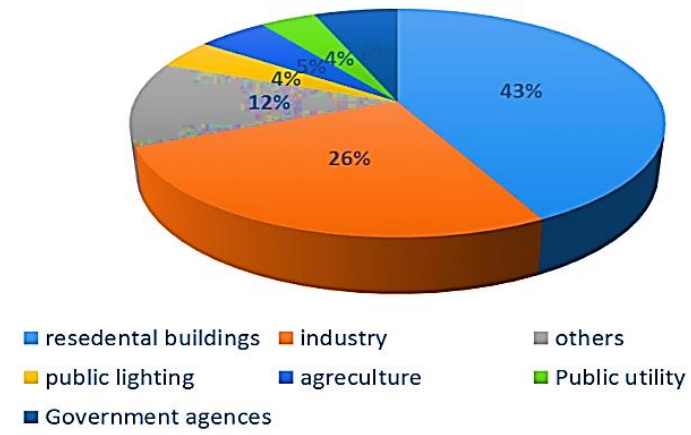

Figure 6 Energy consumption in Egypt according to activity [2] 
Subsequently, the energy consumption during the building phases could be classified as follows; [8]

Table 3 Energy consumption during building phases $[9,10]$

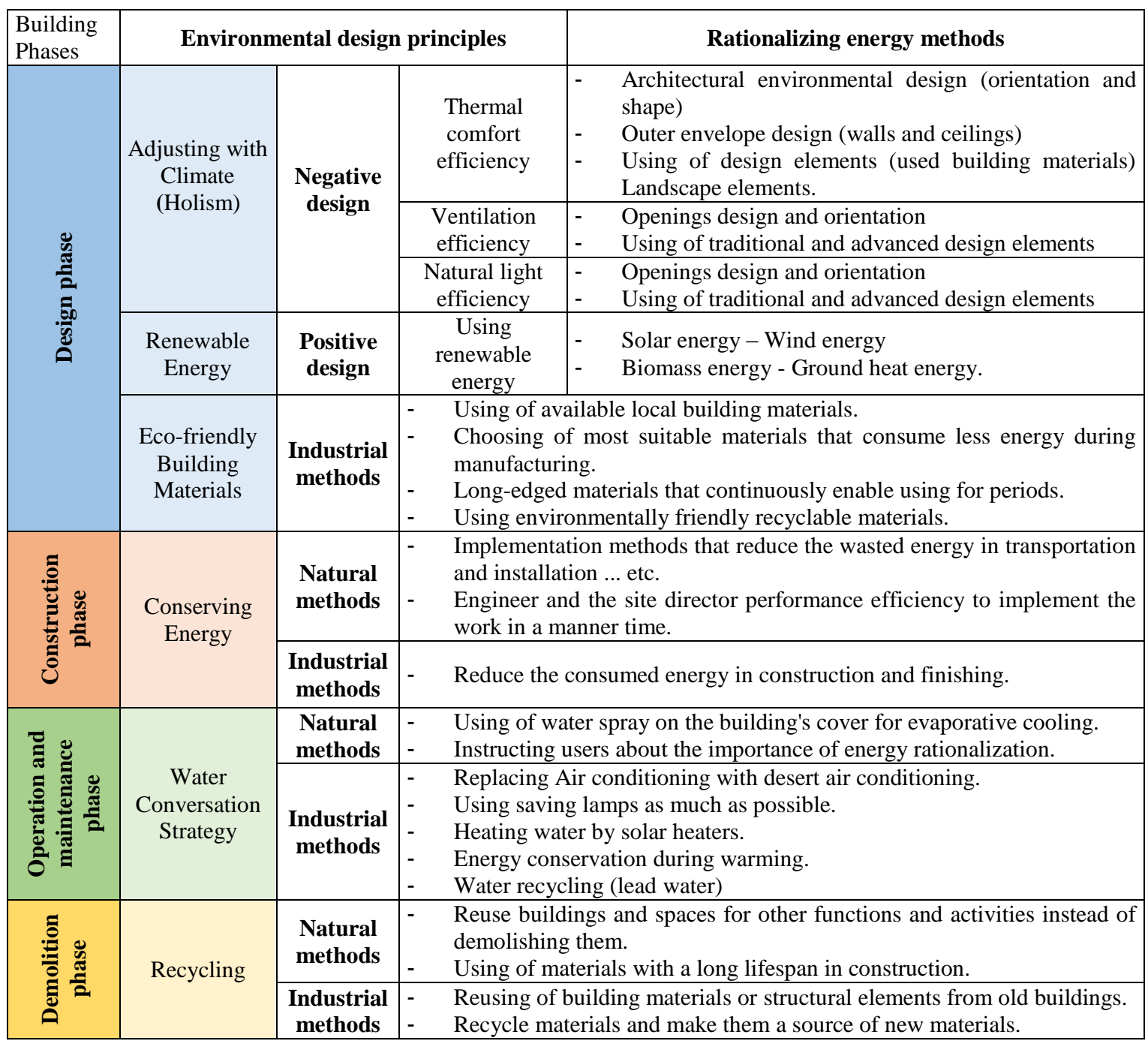

\subsubsection{Energy consumption in the design phase}

In design phase, we can define the building's shape and orientation, geographical location, nature of its work, selection of the cladding components or building service systems, and many design decisions that have a direct and indirect impact on the building's energy consumption.

\subsubsection{Energy consumption in the construction phase}

In each stage of the building material's life, it consumes energy and produces harmful wastes. Therefore, the materials production's energy includes all processes of extraction, processing, disposal or reused, which is called the material life cycle, so the closed material life cycles the less the negative waste. 


\subsubsection{Energy consumption in the operation and maintenance phase}

It means the energy consumption that help the building to perform its function, and achieve the comfort levels for users by utilizing the building systems that responsible for lighting, ventilation, cooling, and heating, as well as the consumed energy by the equipment and devices. It varies depending on the building type and the usage nature. There are many ways that help in the rationalizing energy consumption during the operation phase, including the use of negative design methods by using natural lighting, that includes negative cooling, ventilation and heating systems, and selecting cooling and heating high-efficiency systems.

\subsubsection{Energy consumption in the demolition phase}

It includes the required energy for demolition process, by involving the potential energy during materials' construction or post-implementation construction, which expected to obtain with minimal waste. Table 3 shows energy consumption during different building stages, and the methods that help in rationalizing energy consumption [9].

\subsection{Rationalization in energy consumption}

This part deals with the definition of rationalization in energy consumption, and the rationalization fields through different building elements.

\subsubsection{Rationalization concept of energy consumption}

It means the best consumption of energy resource, to limit the waste without compromising the user's comfort and productivity or the efficiency of the used equipment. Accordingly, this objective is attained by means of the wise operation methods in various consumption's sectors. These benefits can be summarized as follows:

- Optimal utilization of non-renewable energy sources, which helps to preserve these sources for next generations.

- Reducing fuel consumption, which help in improving the environment.

- Make provisions in the energy sector, helps to develop other fields.

- Reduce the amount of energy consumed and thus reduce the consumption bill on users.

\subsubsection{Fields of rationalizing energy consumption}

Energy consumption can be rationalized via two methods; First, by rationalizing the current energy, so it can reduce the waste amount of consuming energy. Second, depends on the future energy, with long-term rationalization by replacing current energy with permanent efficiency one.

The fields of energy rationalization in the building and improving the efficiency of its use could be defined in the following elements, as in Table 4: 
Table 4 Methods Of Rationalizing Energy Consumption [11,12]

\begin{tabular}{|c|c|}
\hline $\begin{array}{l}\text { Methods Of } \\
\text { Rationalizing } \\
\text { Energy } \\
\text { Consumption }\end{array}$ & Application \\
\hline $\begin{array}{l}\text { Related To } \\
\text { Equipment, Tools } \\
\text { And Used Devices }\end{array}$ & $\begin{array}{l}\text { The building needs to reduce the required energy for lighting, cooling, and heating, by selecting } \\
\text { efficient appliances either electrical, or air conditioning systems to achieve high efficiency that } \\
\text { require less power. In Egypt, the General Organization for Standardization and Quality of the } \\
\text { Industry and Commerce Ministry sets the standards for most energy-efficient household } \\
\text { appliances, that required a placed sticker on the device in a visible place to recognize the degree } \\
\text { of energy efficiency and help users make the decision. }\end{array}$ \\
\hline $\begin{array}{l}\text { Related To } \\
\text { Energy- } \\
\text { Consuming } \\
\text { Systems } \\
\end{array}$ & $\begin{array}{l}\text { The misuse of equipment (heating, cooling, lighting, etc.) tends to lose energy even if it is highly } \\
\text { efficient. Subsequently, mechanical instead of manual systems are used to manage energy to } \\
\text { provide control that reduces energy consumption and costs. }\end{array}$ \\
\hline $\begin{array}{l}\text { Related To The } \\
\text { Building Itself and } \\
\text { The Surrounding } \\
\text { Elements }\end{array}$ & $\begin{array}{l}\text { Energy consumption in buildings is rationalized during design and implementation stages in } \\
\text { accordance with environmental standards, taking into account the adaptation with the } \\
\text { surrounding environmental, geographical and climatically conditions to increase its thermal } \\
\text { efficiency. }\end{array}$ \\
\hline $\begin{array}{l}\text { Related to the } \\
\text { Outer Envelope } \\
\text { Design; }\end{array}$ & $\begin{array}{l}\text { The outer envelope plays an important role in separating the outside climate conditions and the } \\
\text { inside required functions to achieve comfort levels in the building. Therefore, the outer envelope } \\
\text { type and the used techniques should be studied to take in consideration the energy conservation } \\
\text { in the building. }\end{array}$ \\
\hline $\begin{array}{l}\text { Related To The } \\
\text { Building's Users }\end{array}$ & $\begin{array}{l}\text { Training of the building's users help in achieving low energy buildings by using cooling and } \\
\text { negative heating systems in an optimal way. Accordingly, this is done via the development } \\
\text { awareness programs in the audio, video media and the civil-society system, especially from } \\
\text { individual behavior. }\end{array}$ \\
\hline
\end{tabular}

\subsection{Classification of buildings according to energy consumption}

This classification depends on the intensity of building's energy consumption, and compares it with same buildings' types that meet standards and requirements of construction. These buildings can be classified into; intensive-energy buildings, lowenergy buildings, zero-energy buildings, with ensuring that the users' comfort levels and the building performance are kept efficiently [1], Fig. 7.

\subsection{Measuring programs and systems for energy in buildings:}

There are many energy simulation programs that could analyze by using an interactive interface different inputs via various design structures and calculation equations. These tools are used in the design stage to make different decisions that effect on the energy consumption in the following stages mainly in operation and maintenance phase and directing the developing design. The most famous program is HEED program, that combines the energy simulation search engine in buildings with an easy interface [13].
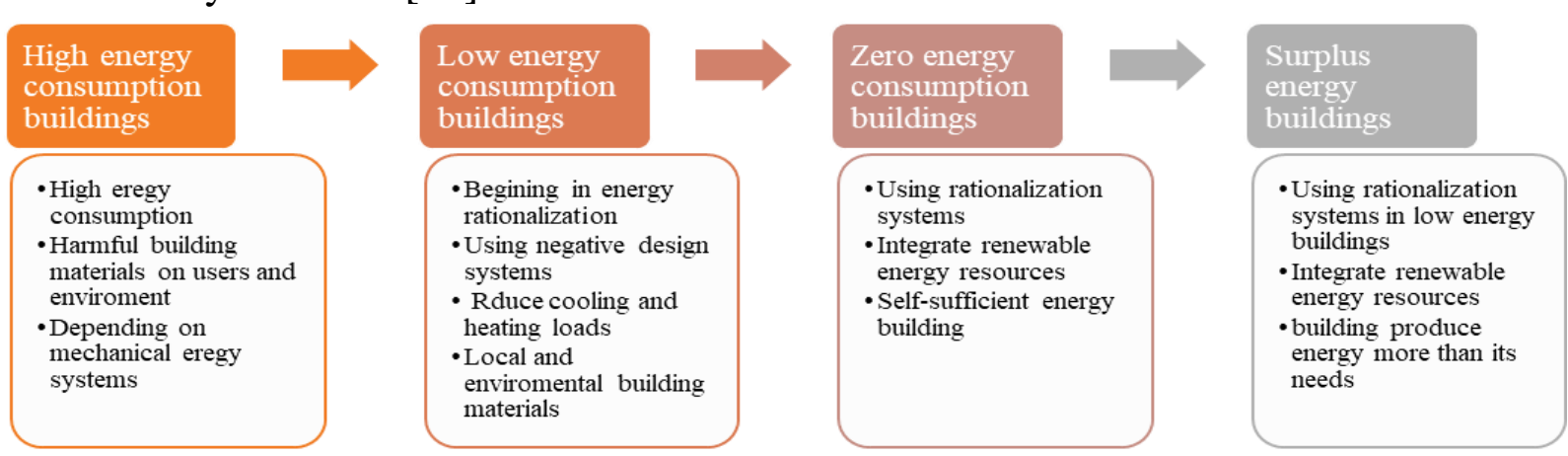

Figure 7 Building levels according to energy consumption [Author] 


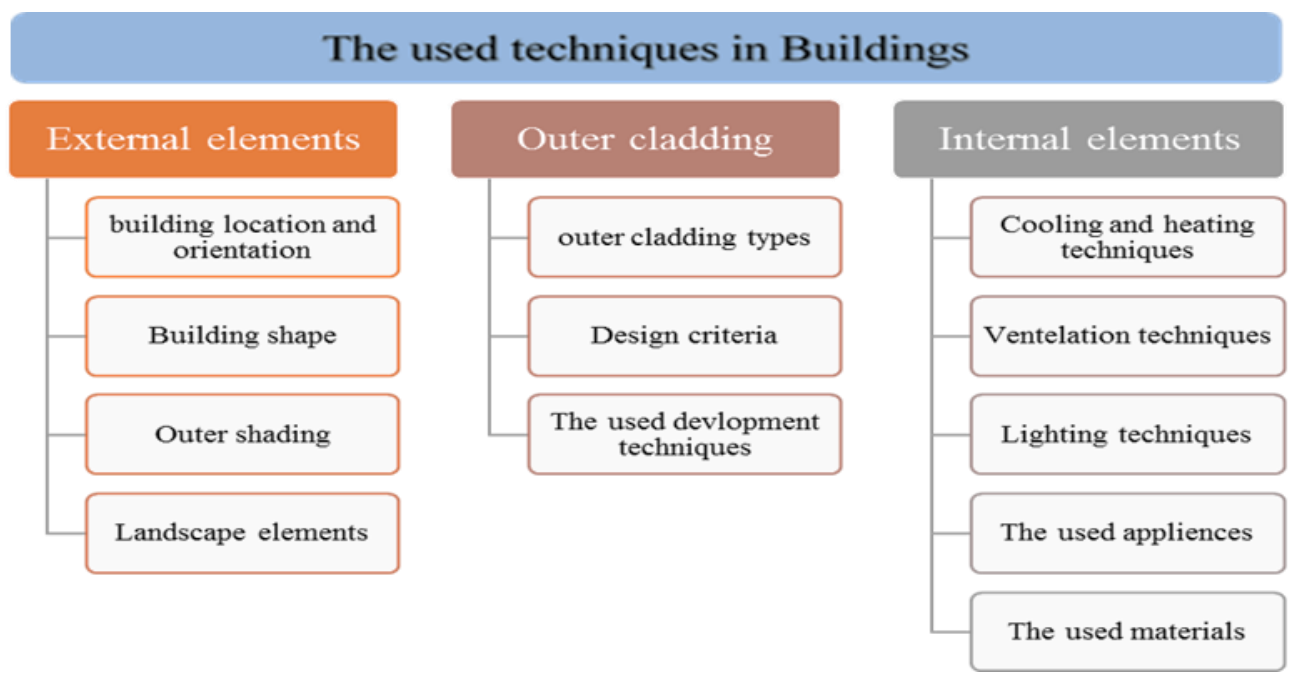

Figure 8 New techniques classification according to place in the building [Author]

\section{Modern Techniques in Buildings}

The research deals with the concept of using modern techniques in buildings and their classification according to their location in the building. These techniques cannot be separated from each other, due to the mutual influence on each other either directly or indirectly with varying amounts. Consequently, the research assumed theoretically divided these elements to facilitate their study, into three sectors, Fig. 8.

\subsection{External elements}

The external elements provide shading for buildings by preventing thermal radiation from the surroundings, to control the ambient temperature. These elements are; orientation, geographical location, building shape, external shading and landscape elements, which play a vital role in reducing thermal loads and helping in energy rationalization [12].

\subsection{Outer envelope}

The building's outer envelope is a direct expression of the used functional and structural elements in the building facade, whether concrete, iron, glass or other construction materials. Besides, the building outer envelope is the link between the inside and the outside, and affects by the noise, heat or overcome external climatic conditions for the user's convenience. Thus, the outer envelope design is affected by many factors [14]:

- External factors: which include external air temperature, wind speed and direction, relative humidity and the amount of solar radiation.

- Internal factors: such as internal air temperature, surface temperature, air change's rate, relative humidity and lighting intensity.

- The design of the outer envelope: successful envelopes take into consideration the functional standards (ventilation, natural lighting, acoustic performance, thermal insulation, shading, photovoltaic cells, passive design, cooling and 
heating), structural, aesthetic and environmental availability. As a result, by using new techniques in the outer envelope design such as; smart materials, power generation materials, dynamic casings, solar skis, etc., especially with the emergence of nanotechnology will increase all the materials efficiency.

For example, in Champillion building at Dubai that used hexagonal units to form the outer envelope from many layers of glass and solar panels on a structural frame. These units are aligned mechanically with the sun, closed to block the sun or open to inter the natural lighting inside the building. In addition, the outer envelope contains layers of micro-energy generating cells that generate power during the day and provide energy during working hours, Fig. 9.

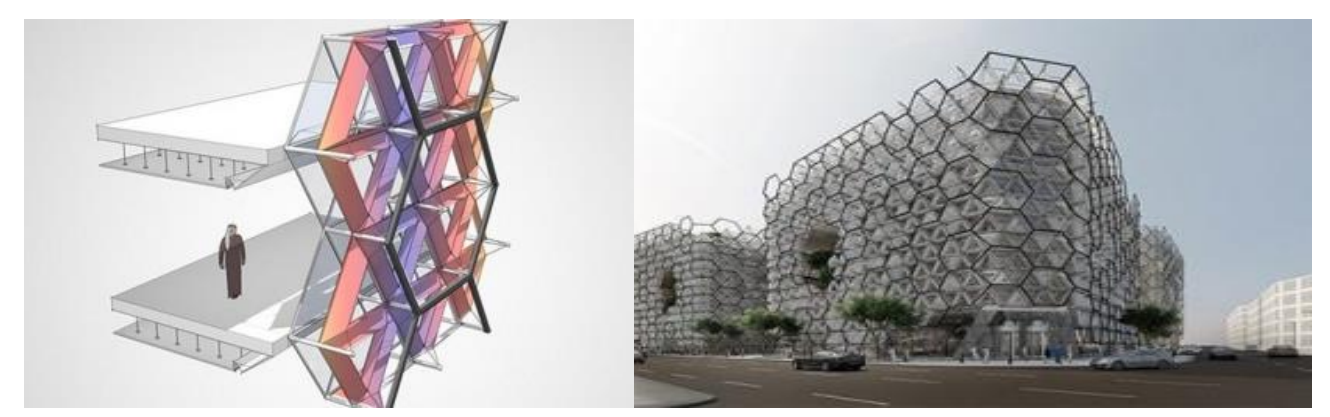

\subsection{Internal elements}

Figure 9 Champillion building in Dubai [15]

Internal elements that affect energy consumption in buildings, involve service systems to achieve the users' comfort levels, which vary from ventilation, cooling and heating, lighting systems, and the selected building's materials.

\subsubsection{Lighting}

The required lighting for comfort levels in spaces affects by the used strategies of energy rationalization in the building, which depend on: the building type, internal spaces, work nature, and the operating and lighting periods that has two main types [15]:

- Natural Lighting; For building operation, natural lighting greatly reduces the required energy in the internal spaces, by taking into account the site and building shape. Accordingly, the factors that maximize the benefits of natural lighting are; the building location and shape, external openings ratios, the used glass, and the geometric shape of internal space.

- Artificial Lighting; Artificial lighting is used as an auxiliary element for natural lighting to achieve proper lighting for the internal space, such as LED illuminations that are used currently to minimize consumption as much as possible. Therefore, control systems help to combine natural and artificial lighting in spaces by several strategies, such as using of wireless sensors that close or reduce the intensity of artificial light according to the occupied spaces at certain periods of time, or according to the amount of the external lighting.

\subsubsection{Ventilation}

The natural ventilation in the internal spaces depends on the differences in the temperature and pressure between inside and outside to create the wind 
movement, which is considered the most important factors affecting the energy consumption; this happened in two ways [16]:

- Natural ventilation; Windows helps in natural ventilation by avoiding the heat lose during the winter and allow the fresh air to pass through the outer envelope in moderate heat periods during the year. Besides, some architectural elements can be used such as; solar chimneys or air intakes to benefit from the natural air ventilation in the internal spaces.

- Mechanical ventilation; To keep the air change's rate constant in the internal spaces, it is better to use mechanical ventilation units that are responsible for providing fresh air and disposal of bad air, especially in non-natural ventilation spaces. These are suction units with filters and delivered air pipes.

\subsubsection{Cooling and heating:}

Cooling and heating requirements must be designed carefully, due to it affected on the building cost and operating expenses. So, thermal comfort levels can be achieved via several strategies [17]:

- Negative cooling and heating strategies: by using of conductivity, radiation load, evaporation features, and using of the environment as natural sources of energy "Sink Heat". Therefore, their use in buildings help in creating sustainable buildings and reduce consuming fuel to achieve comfort thermal levels.

- Using of mechanical cooling and heating systems: which are divided into; airbased systems such as; window air conditioning, split units, and air-conditioning with tubes, and water-based systems, that are divided according to the coolant type into; water-cooled and the air-cooled system, Fig. 10.

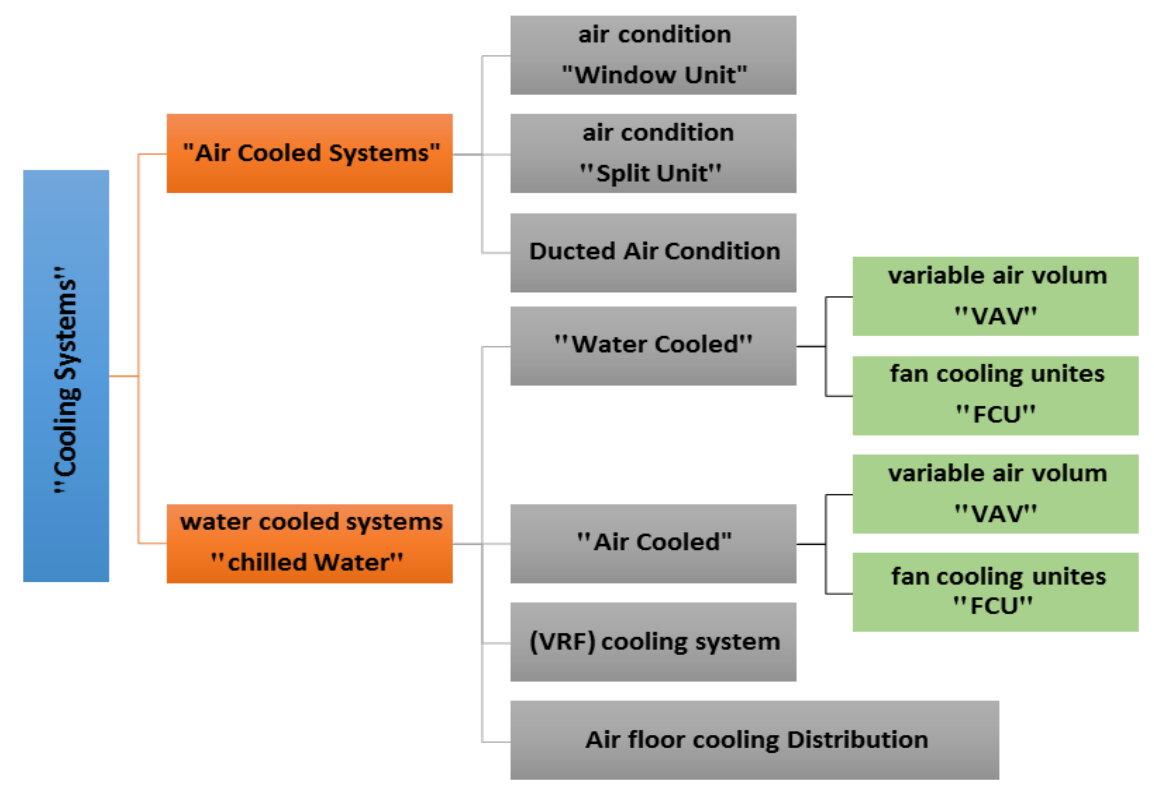

Figure 10 Mechanical cooling and heating systems [18]

- Cooling and heating control systems: used in controlling the air amount's levels, temperature and humidity to achieve the users' comfort levels. In consequence, a fully control of each space by sensors helped in energy rationalization that used in the building operation. 


\subsubsection{The used materials}

Building materials consumed energy during three phases in parallel to the construction stages itself. Starting with; the pre-construction phase of material extraction, manufacturing and transport, then the construction phase of the implementation, installation, maintenance, and post-construction phase, which includes final disposal either by reusing or recycling [18].

The selection of building materials must be evaluated to meet the environmental sustainability standards. Subsequently, these standards related to the building's life cycle and includes efficiency standards for material sources, internal environment quality, and energy efficiency standards. The technological development in the construction field led to many building material's productions with advanced properties. Such as; the nanotechnology and the enormous potentials of smart materials to support the building's performance and improve rationalization of energy consumption, either in structural or compatible materials [17], Fig. 11.

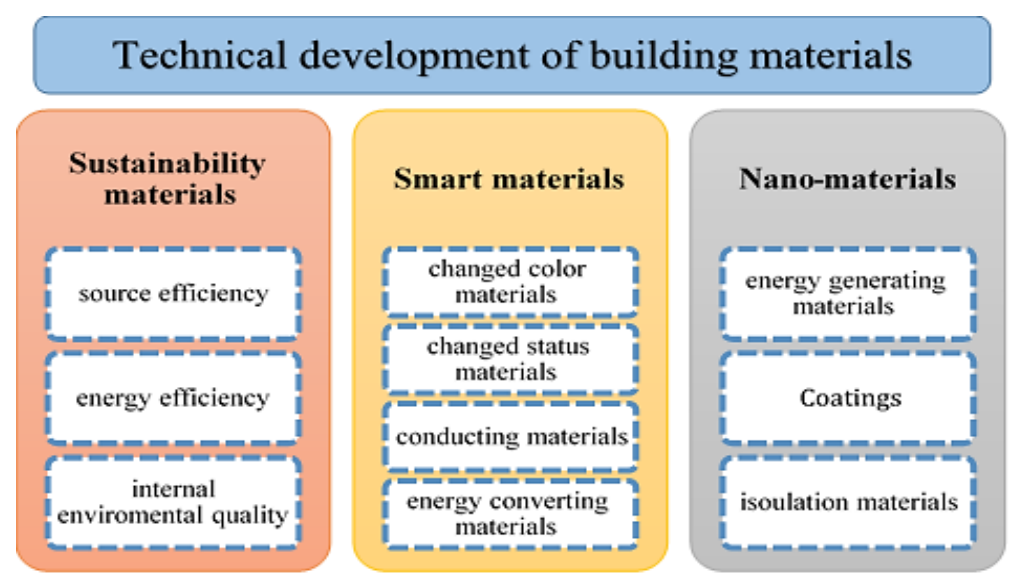

Figure 11 Technological development in the construction materials [17]

\section{Analytical study}

In this section, some case studies were analyzed, these buildings used modern techniques in different building elements (external elements, outer envelope, internal elements), which effect on energy consumption. In order to reach the correlation between the used technologies and rationalization of energy consumption, helped in attaining a methodological design of energy rationalization in buildings, that can be utilized and applied either on new or existing buildings. A descriptive, analytical methodology is used for this purpose, though three tables describe the used technique and its evaluation by colored points; 1 for 'weak', 2 for 'moderate', and 3 for 'good' in their application in buildings.

\subsection{Case Studies}

The selected buildings attained the usage of modern technologies to achieve the functional efficiency and energy rationalization. These buildings won international awards, and obtained the accreditation of an international organization of evaluating energy efficiency. 


\subsubsection{Institution \& exhibition of earth environmental, Renzo Piano, 2008}
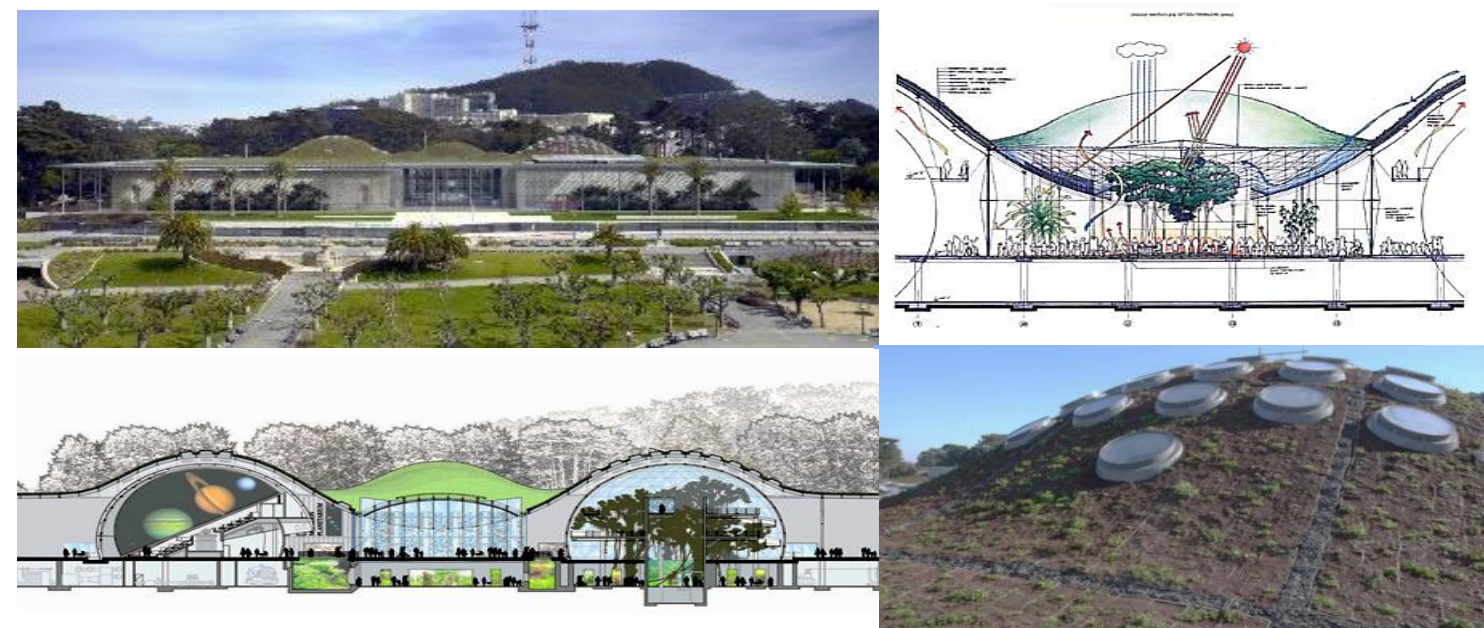

Figure 12 Institution \& exhibition of earth environmental [19]

Table 5 Evaluation of used techniques in Institution \& exhibition of earth environmental [20]

\begin{tabular}{|c|c|c|c|c|c|c|c|c|c|c|c|c|c|c|c|c|c|c|c|c|c|c|}
\hline \multicolumn{23}{|c|}{ Outer envelope } \\
\hline \multirow[b]{3}{*}{ 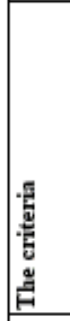 } & \multicolumn{19}{|c|}{ Energy rationalization } & \multirow{2}{*}{\multicolumn{3}{|c|}{$\begin{array}{l}\text { Energy } \\
\text { generation }\end{array}$}} \\
\hline & \multicolumn{7}{|c|}{ Design elements } & \multicolumn{5}{|c|}{ Technical elements } & \multicolumn{7}{|c|}{ The used materials } & & & \\
\hline & 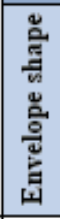 & 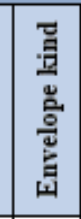 & 렬 혈 혈 & 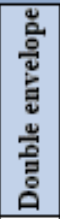 & 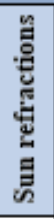 & $\begin{array}{l}0 \\
0 \\
0 \\
0\end{array}$ & 党 & 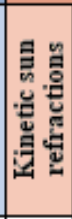 & 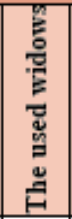 & 告 & 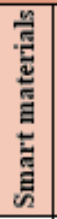 & 常 & 焉造 & 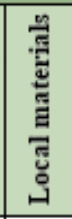 & 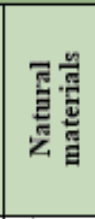 & 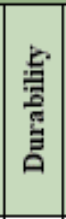 & 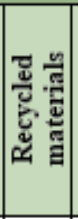 & 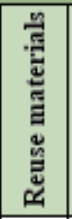 & . & 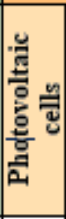 & 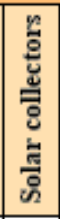 & 密 \\
\hline 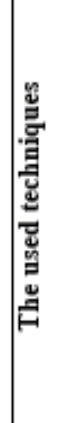 & & 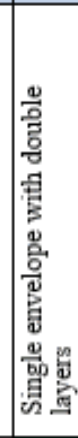 & 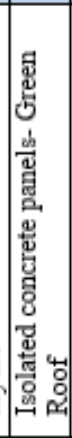 & 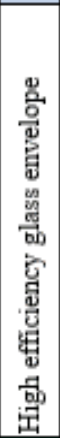 & 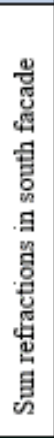 & 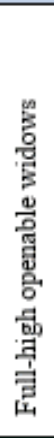 & & 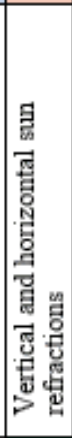 & 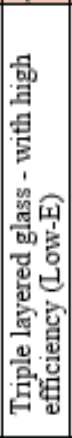 & 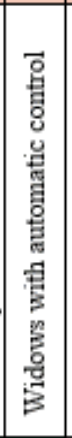 & & & 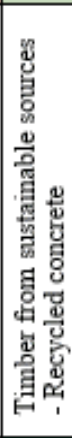 & 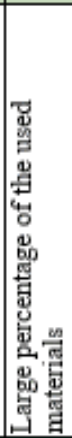 & 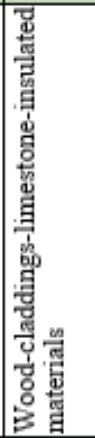 & 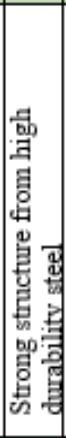 & 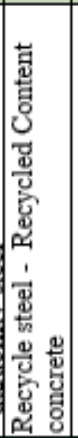 & 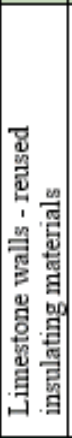 & 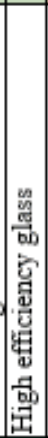 & 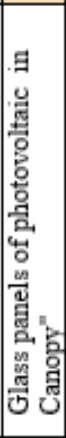 & & \\
\hline \multirow{3}{*}{ 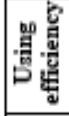 } & & & & & & & & & & & & & & & & & & & & & & \\
\hline & & & & & & & & & & & & & & & & & & & & & & \\
\hline & & & & & & & & & & & & & & & & & & & & & & \\
\hline \multicolumn{23}{|c|}{$\begin{array}{l}\text { - Insulation: All building elements are good insulated, starting from the roof with the plant cover, using of } \\
\text { prefabricated concrete units in walls "Structural Insulated Panels", and the northern facades are of transparen } \\
\text { glass with high coefficient efficiency. } \\
\text { The used windows are from three layers Low-E glass with low absorption coefficient, for protection from the sur } \\
\text { and to benefit from natural lighting. } \\
\text { - Structural skeleton: was made from high durability, recyclable and reusable metal. Reinforced concrete with } \\
\text { recycled content, a large proportion of cement was replaced with fly ash. }\end{array}$} \\
\hline
\end{tabular}


Randa Reda Kamel /et al/Engineering Research Journal 162 (June 2019) A19- A

Table 5 continued

\begin{tabular}{|c|c|c|c|c|c|c|c|c|c|c|c|c|c|c|c|c|}
\hline \multirow[b]{3}{*}{ 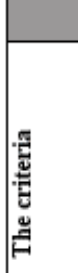 } & \multicolumn{16}{|c|}{ External elements } \\
\hline & \multicolumn{5}{|c|}{ Building features } & \multicolumn{11}{|c|}{$\begin{array}{lc}\text { External elements } \\
\end{array}$} \\
\hline & 量 & 量量 & 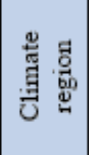 & 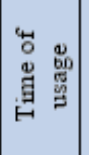 & Ðّ & \multicolumn{2}{|c|}{ 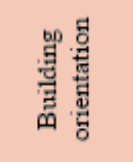 } & 昜。 & \multicolumn{2}{|c|}{ 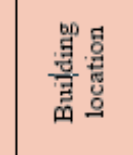 } & \multicolumn{2}{|c|}{ 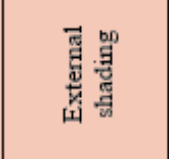 } & & & \multicolumn{2}{|c|}{ 苞 } \\
\hline 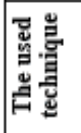 & \multirow{2}{*}{ 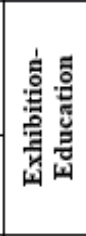 } & \multirow{2}{*}{ 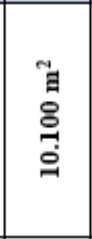 } & \multirow{2}{*}{ 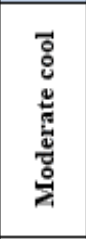 } & \multirow{2}{*}{ 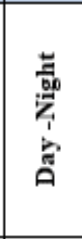 } & & \multicolumn{2}{|c|}{$\begin{array}{l}\text { East west } \\
\text { direction }\end{array}$} & \begin{tabular}{|c|} 
Huge \\
rectangle \\
with \\
Atriums \\
\end{tabular} & \multicolumn{2}{|c|}{$\begin{array}{l}\text { Urban } \\
\text { areas }\end{array}$} & \multicolumn{2}{|c|}{$\begin{array}{c}\text { Green Roofs, } \\
\text { Overhang } \\
\text { Canopy }\end{array}$} & \multicolumn{2}{|c|}{$\begin{array}{l}\text { Good usage of } \\
\text { plant elements }\end{array}$} & \multicolumn{2}{|c|}{$\begin{array}{l}\text { Using simulation } \\
\text { programs }\end{array}$} \\
\hline 尊 & & & & & & 鹴 & 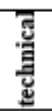 & 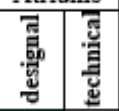 & 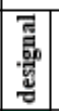 & 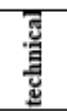 & $\begin{array}{l}\text { 霩 } \\
\text { 噌 }\end{array}$ & $\begin{array}{l}\text { 矛 } \\
\text { 递 }\end{array}$ & $\begin{array}{l}\text { 需 } \\
\text { 莺 }\end{array}$ & 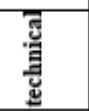 & 霝 & 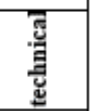 \\
\hline 悹 & & $\checkmark$ & & & & & & & & & & & & & & \\
\hline 设 & 1 & $v^{2}$ & 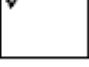 & $v^{v}$ & & & & & & & & & & & & \\
\hline 䓵 & & $\begin{array}{l}\text { uilding } \mathrm{i} \\
\text { ghting, v } \\
\text { ith photc }\end{array}$ & & & & & & $\begin{array}{l}\text { s negative } \\
\text { Besides t } \\
\text { lass panel }\end{array}$ & & & & & & 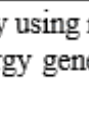 & & $\begin{array}{l}\text { rgies in } \\
\text { hniques }\end{array}$ \\
\hline & $\begin{array}{l}\text { La } \\
\text { ent } \\
\text { red }\end{array}$ & $\begin{array}{l}\text { andscap } \\
\text { vironme } \\
\text { duce hez }\end{array}$ & & ection. & & & & $\begin{array}{l}\text { ering desi } \\
\text { cts as an }\end{array}$ & & & & & & een Roc & & s many \\
\hline
\end{tabular}

Table 5 continued

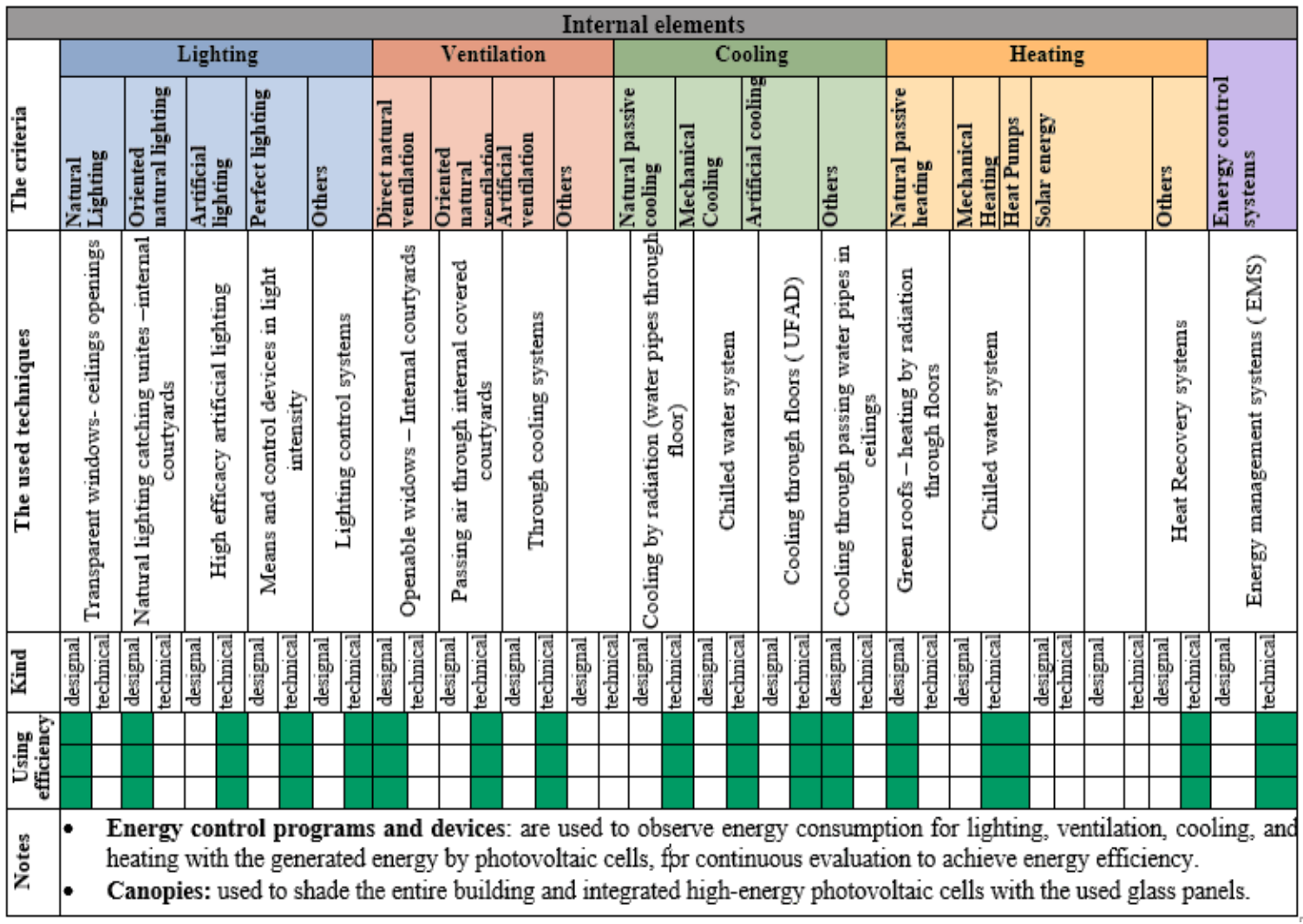




\subsubsection{Siemens Head quartz, Masdar City, Sheppard Robson, 2014}
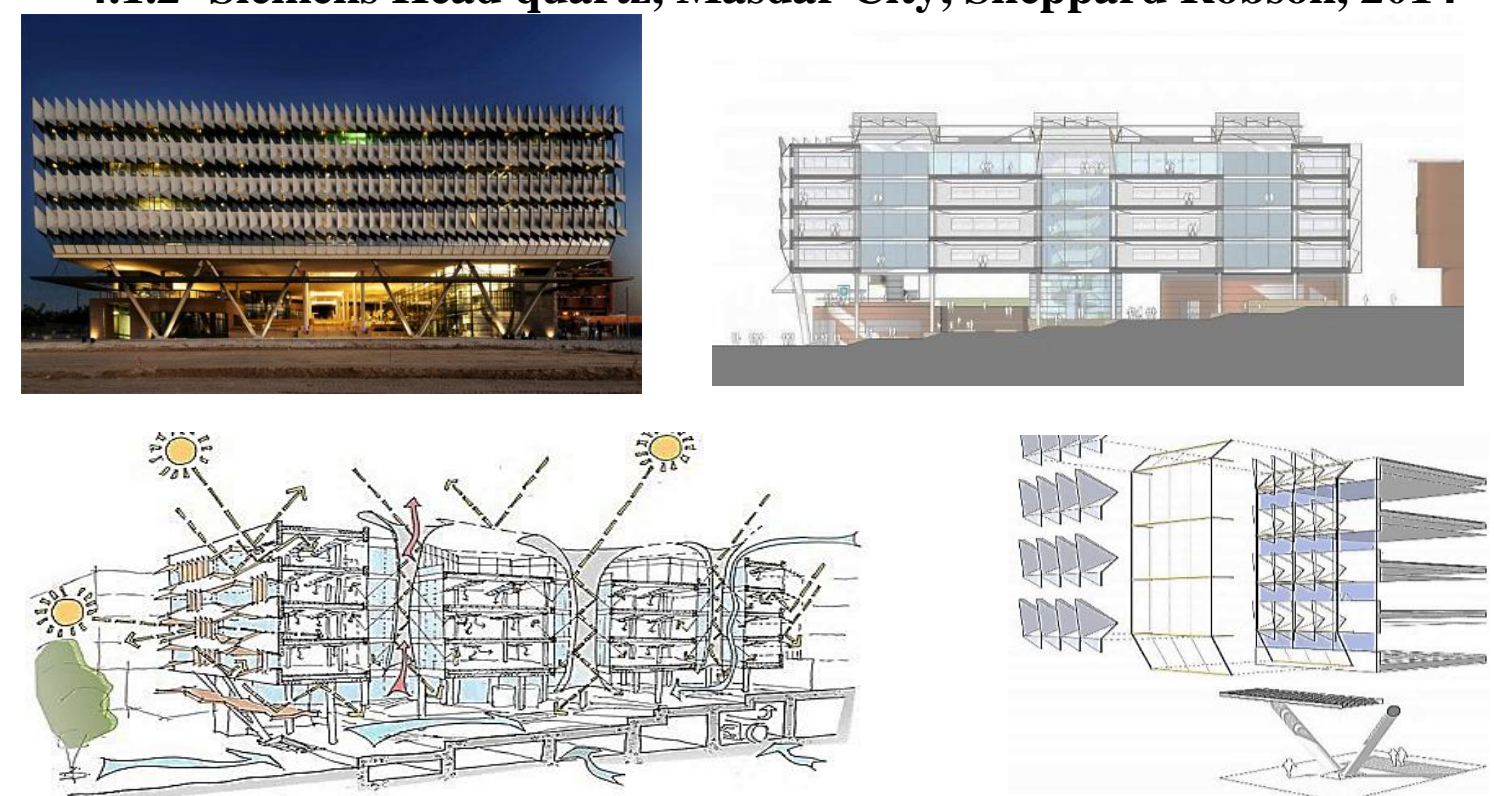

Figure 13 Siemens Head quartz, Masdar City [21] [22]

Table 6 Evaluation of used techniques in Siemens Head quartz, Masdar City [22]

\begin{tabular}{|c|c|c|c|c|c|c|c|c|c|c|c|c|c|c|c|c|c|c|c|c|c|c|}
\hline \multicolumn{23}{|c|}{ Outer envelope } \\
\hline \multirow[b]{3}{*}{ 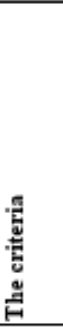 } & \multicolumn{19}{|c|}{ Energy conservation } & \multirow{2}{*}{\multicolumn{3}{|c|}{ Energy generation }} \\
\hline & \multicolumn{7}{|c|}{ Design elements } & \multicolumn{5}{|c|}{ Technical elements } & \multicolumn{7}{|c|}{ The used materials } & & & \\
\hline & 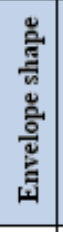 & 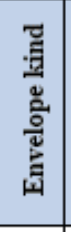 & 즘영 & 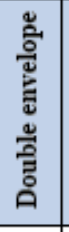 & 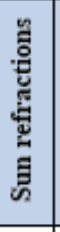 & 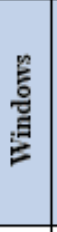 & 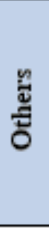 & 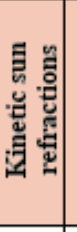 & 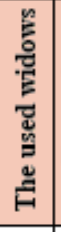 & 㔛总 & 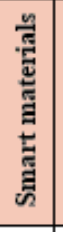 & 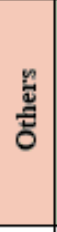 & 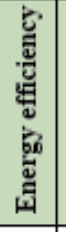 & 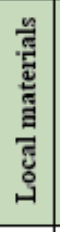 & 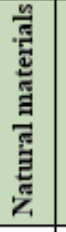 & 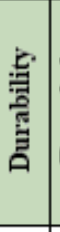 & 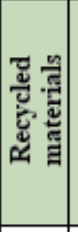 & 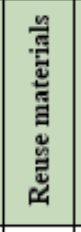 & 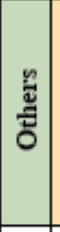 & 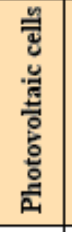 & 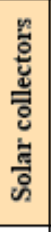 & 品 \\
\hline 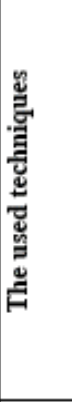 & & 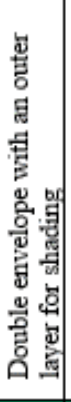 & 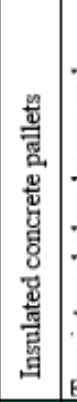 & 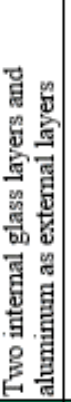 & 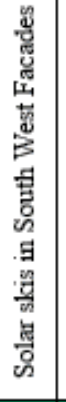 & 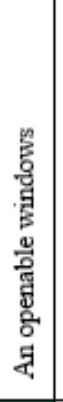 & & 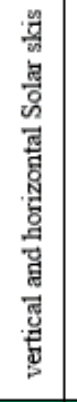 & 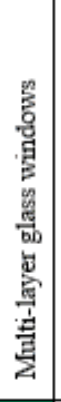 & & & & 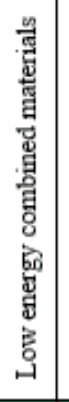 & 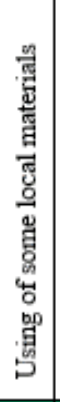 & 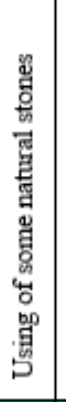 & 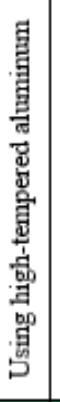 & 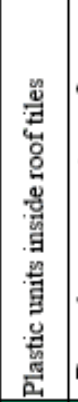 & 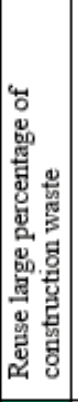 & & & & \\
\hline 它 & & & & & & & & & & & & & & & & & & & & & & \\
\hline & & & & & & & & & & & & & & & & & & & & & & \\
\hline & & & & & & & & & & & & & & & & & & & & & & \\
\hline 选 & $\begin{array}{ll}\cdot & 1 \\
& 1 \\
\cdot & 1 \\
& 1 \\
\cdot & 1 \\
& 1 \\
& 1 \\
\end{array}$ & $\begin{array}{l}\text { Insul } \\
\text { curtai } \\
\text { The u } \\
\text { colum } \\
\text { The } \\
\text { units } \\
\text { used }\end{array}$ & $\begin{array}{l}\text { ased } \\
\text { ans } \\
\text { used } \\
\text { insi }\end{array}$ & & & & & b & high & sib & $\begin{array}{l}\text { kis, } \\
\text { bility } \\
\text {-tensi } \\
\text { olum }\end{array}$ & $\begin{array}{l}\text { i } \\
\text { io } \\
\text { io }\end{array}$ & $\begin{array}{l}\text { id } \\
\text { inte } \\
15 \\
\text { nit } \\
\text { ing }\end{array}$ & $\begin{array}{l}\text { eri } \\
5 \text { i } \\
\text { tes }\end{array}$ & ce & $\begin{array}{l}\text { inne } \\
\text { ce fo } \\
\text { desi } \\
\text { integr } \\
\text { ete u }\end{array}$ & $\begin{array}{l}\text { lay } \\
\text { or the } \\
\text { ign. Th } \\
\text { usated } \\
\text { usage, }\end{array}$ & $\begin{array}{l}\text { he adn } \\
\text { void- } \\
\text { and } \mathrm{s}\end{array}$ & $\min i$ & & & $\begin{array}{l}1 \text { glass } \\
\text { ces are } \\
\text { plastid } \\
50 \% \text { of }\end{array}$ \\
\hline
\end{tabular}


Randa Reda Kamel /et al/Engineering Research Journal 162 (June 2019) A19- A

Table 6 continued

\begin{tabular}{|c|c|c|c|c|c|c|c|c|c|c|c|c|c|c|c|c|c|}
\hline \multicolumn{18}{|c|}{ External elements } \\
\hline \multirow[b]{2}{*}{ 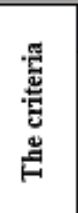 } & \multicolumn{5}{|c|}{ Building features } & \multicolumn{12}{|c|}{$\begin{array}{ll}\text { External elements } \\
\end{array}$} \\
\hline & 悬 总 & 暈亳 & 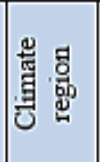 & 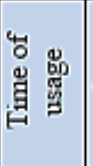 & 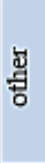 & \multicolumn{2}{|c|}{ 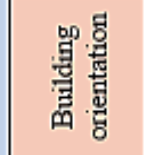 } & \multicolumn{2}{|c|}{ 量 善 } & \multicolumn{2}{|c|}{ 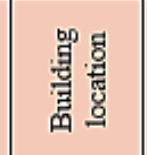 } & \multicolumn{2}{|c|}{ 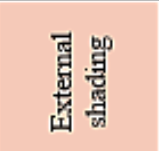 } & \multicolumn{2}{|c|}{ 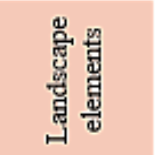 } & \multicolumn{2}{|c|}{ छี } \\
\hline 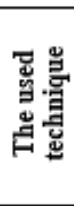 & \multirow{2}{*}{ 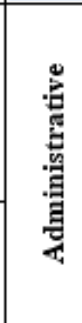 } & \multirow{2}{*}{$\begin{array}{l}\text { ] } \\
\text { 今. } \\
\text { ci } \\
\text { đi }\end{array}$} & \multirow{2}{*}{$\begin{array}{l}\text { 昜 } \\
\text { ğ } \\
\text { 䒿 }\end{array}$} & \multirow{2}{*}{ 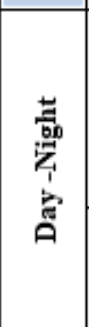 } & & \multicolumn{2}{|c|}{$\begin{array}{l}\text { North East } \\
\text { direction }\end{array}$} & \multicolumn{2}{|c|}{$\begin{array}{l}\text { Huge } \\
\text { square with } \\
\text { Atriums }\end{array}$} & \multicolumn{2}{|c|}{ Urban areas } & \multicolumn{2}{|c|}{$\begin{array}{c}\text { Inner } \\
\text { courtyards } \\
\text { with roof } \\
\text { cover- } \\
\text { surrounding } \\
\text { buildings } \\
\end{array}$} & \multicolumn{2}{|c|}{$\begin{array}{l}\text { The outer } \\
\text { places and } \\
\text { their } \\
\text { association } \\
\text { with the } \\
\text { building }\end{array}$} & \multicolumn{2}{|c|}{\begin{tabular}{c|} 
Use simulation \\
software during the \\
building design to \\
simulate the \\
external elements \\
impact
\end{tabular}} \\
\hline 䔽 & & & & & & 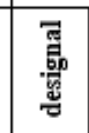 & 宽 & 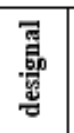 & 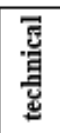 & 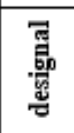 & 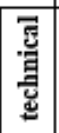 & 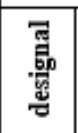 & 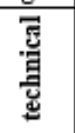 & 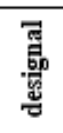 & 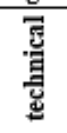 & 覀 & 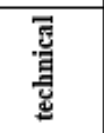 \\
\hline & 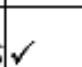 & $\checkmark$ & $\checkmark$ & $\checkmark$ & & & & & & & & & & & & & \\
\hline 遌 & - & & & & & & & & & & & & & & & & tricit \\
\hline
\end{tabular}

Table 6 continued

\begin{tabular}{|c|c|c|c|c|c|c|c|c|c|c|c|c|c|c|c|c|c|c|c|}
\hline \multicolumn{20}{|c|}{ Internal elements } \\
\hline & \multicolumn{5}{|c|}{ Lighting } & \multicolumn{4}{|c|}{ Ventilation } & \multicolumn{4}{|c|}{ Cooling } & \multicolumn{5}{|c|}{ Heating } & \multirow[b]{2}{*}{ 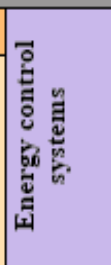 } \\
\hline 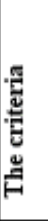 & 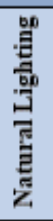 & 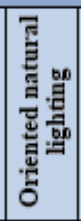 & 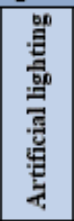 & 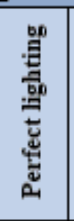 & 胥 & 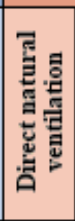 & 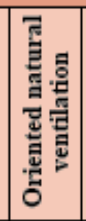 & 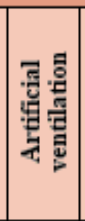 & t) & 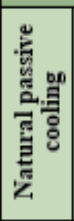 & 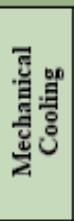 & 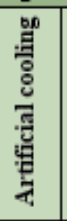 & 总 & 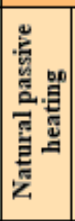 & 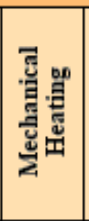 & 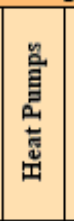 & 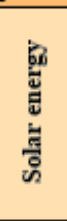 & 焉 & \\
\hline 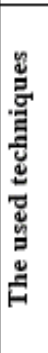 & 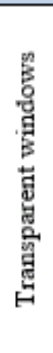 & 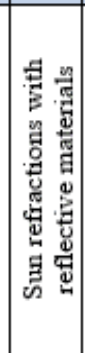 & 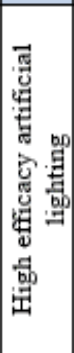 & 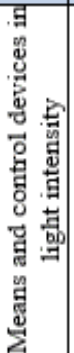 & 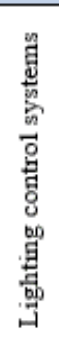 & 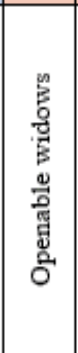 & 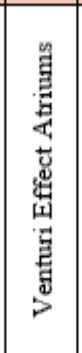 & 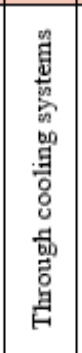 & & 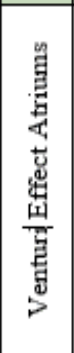 & 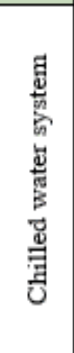 & & & 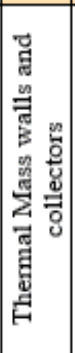 & 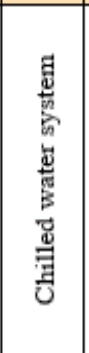 & & & & 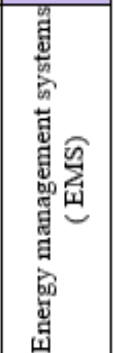 \\
\hline & & E्⿹ & 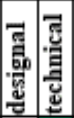 & & & & 㺿 & 预 & & & 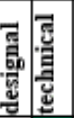 & 预 & 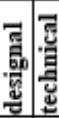 & 氙 & 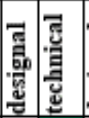 & 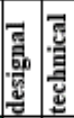 & & & 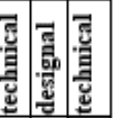 \\
\hline & & & & & & & & & & & & & & & & & & & \\
\hline & & & & & & & & & & & & & & & & & & & \\
\hline & & $\begin{array}{l}\text { Softwa } \\
\text { that cor } \\
\text { Solar s } \\
\text { reflecti } \\
\text { spaces. }\end{array}$ & $\begin{array}{l}\text { kis: } \\
\text { ive }\end{array}$ & & & & & & & & & & & & ond fro & lig & & & $\begin{array}{l}\text { (BMS) } \\
\text { tion. } \\
\text { d highly } \\
\text { h office }\end{array}$ \\
\hline
\end{tabular}




\subsubsection{Al-Dar Central Market Abu Dhabi, Fosters+ Partners, 2010.}

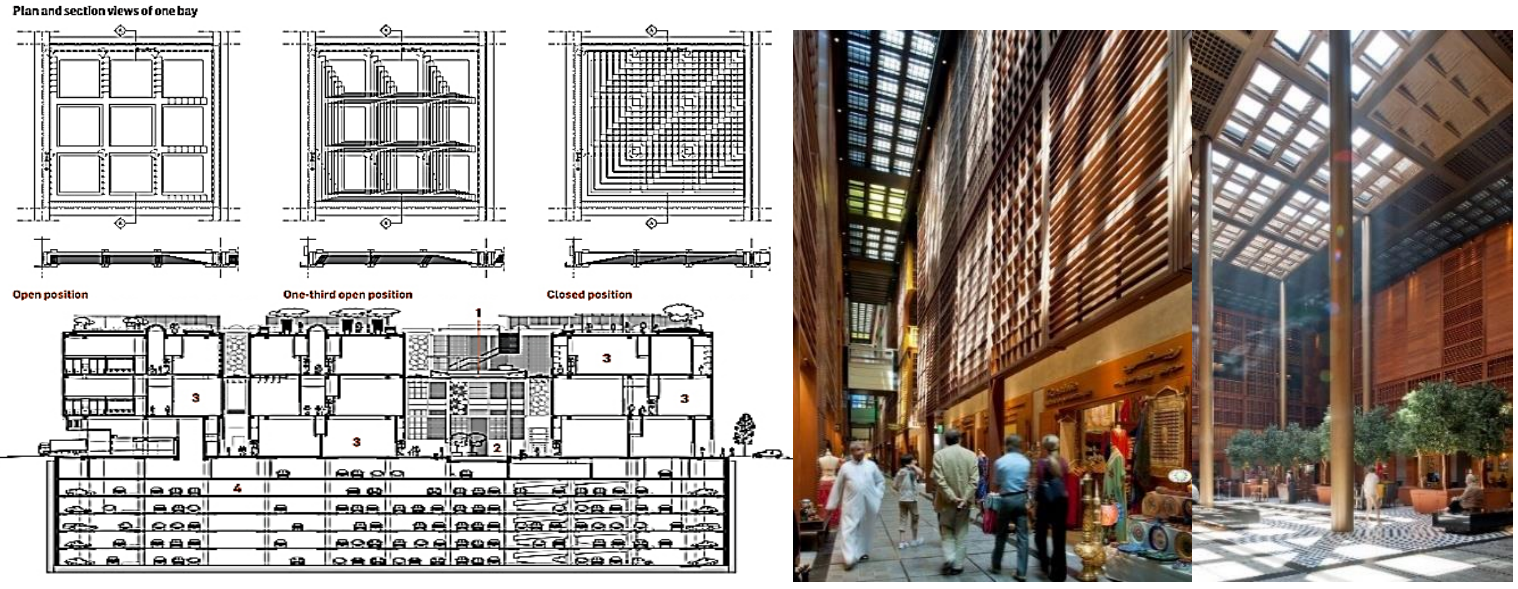

Figure 14 Al-Dar Central Market Abu Dhabi [23] [24]

Table 7 Evaluation of used techniques in Al-Dar Central Market Abu Dhabi [23] [24]

\begin{tabular}{|c|c|c|c|c|c|c|c|c|c|c|c|c|c|c|c|c|c|c|c|c|c|}
\hline \multicolumn{22}{|c|}{ Internal elements } \\
\hline & \multicolumn{5}{|c|}{ Lighting } & \multicolumn{4}{|c|}{ Ventilation } & \multicolumn{5}{|c|}{ Cooling } & \multicolumn{6}{|c|}{ Heating } & \multirow[b]{2}{*}{ 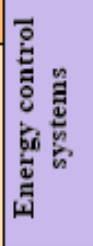 } \\
\hline & 氙最 & 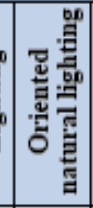 & 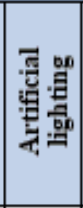 & 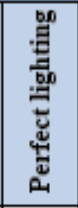 & 岂 & 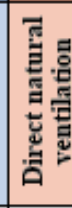 & 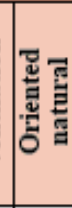 & 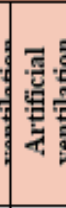 & . & & 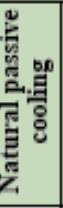 & 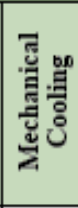 & 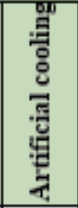 & 岂 & 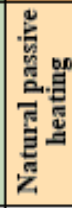 & 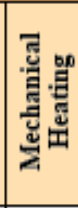 & $\begin{array}{l}\text { 望 } \\
\text { 营 } \\
\text { 至 }\end{array}$ & & 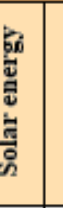 & 壱 & \\
\hline 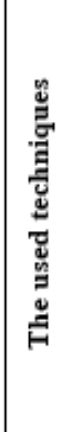 & 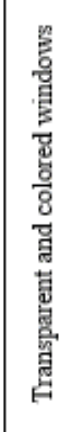 & 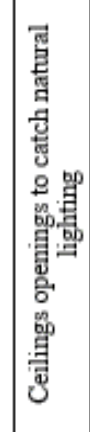 & 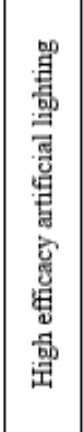 & 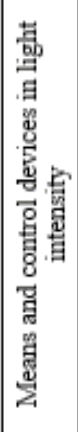 & & 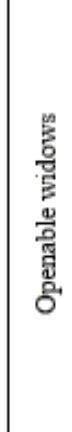 & 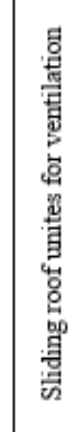 & 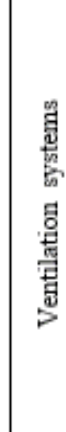 & & & 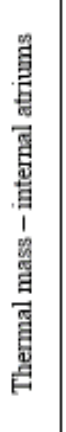 & 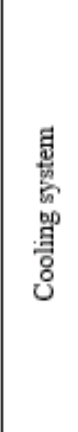 & & & 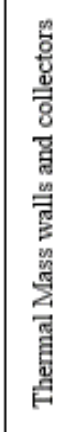 & 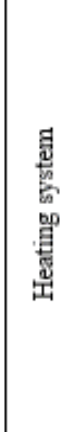 & & & & & 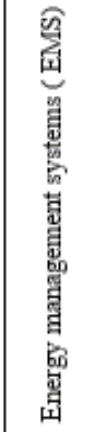 \\
\hline 窨 & 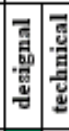 & 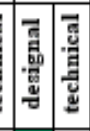 & 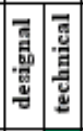 & 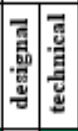 & 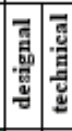 & 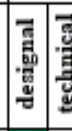 & 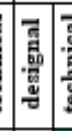 & 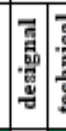 & 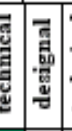 & 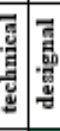 & 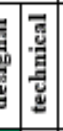 & 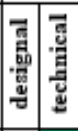 & 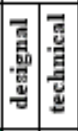 & 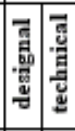 & 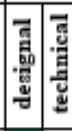 & 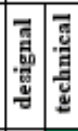 & 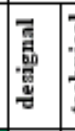 & 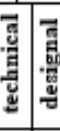 & $\begin{array}{ll} \\
\end{array}$ & 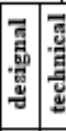 & 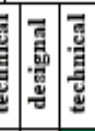 \\
\hline & & & & & & & & & & & & & & & & & & & & & \\
\hline & & & & & & & & & & & & & & & & & & & & & \\
\hline & & & & & & & & & & & & & & & & & & & & & \\
\hline 芒 & . & $\begin{array}{l}\text { vi } \\
\text { fu } \\
\text { Sc } \\
\text { au }\end{array}$ & ligl & 5 & & & & & & & 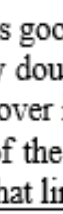 & & & & & & 190 & $1 \mathrm{da}$ & & & adjust \\
\hline
\end{tabular}


Randa Reda Kamel /et al/Engineering Research Journal 162 (June 2019) A19- A

Table 7 continued

\begin{tabular}{|c|c|c|c|c|c|c|c|c|c|c|c|c|c|c|c|c|c|}
\hline \multicolumn{18}{|c|}{ External elements } \\
\hline & \multicolumn{5}{|c|}{ Building features } & \multicolumn{12}{|c|}{$\begin{array}{l}\text { External elements } \\
\end{array}$} \\
\hline 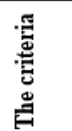 & 悬 & 量塄 & 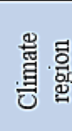 & 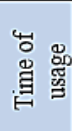 & 홓 & \multicolumn{2}{|c|}{ 恶㺃 } & & & \multicolumn{2}{|c|}{ 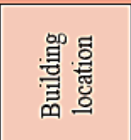 } & & & \multicolumn{2}{|c|}{ 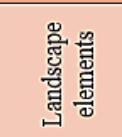 } & \multicolumn{2}{|c|}{ 旁 } \\
\hline 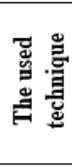 & \multirow{2}{*}{ 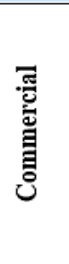 } & \multirow{2}{*}{ 尚 } & \multirow{2}{*}{ 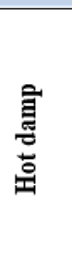 } & \multirow{2}{*}{ 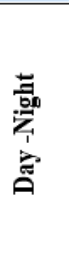 } & & \multicolumn{2}{|c|}{$\begin{array}{c}\text { North } \\
\text { West } \\
\text { direction }\end{array}$} & \multicolumn{2}{|c|}{$\begin{array}{l}\text { Huge } \\
\text { rectangle } \\
\text { with } \\
\text { Atriums }\end{array}$} & \multicolumn{2}{|c|}{$\begin{array}{l}\text { Urban } \\
\text { areas }\end{array}$} & \multicolumn{2}{|c|}{$\begin{array}{l}\text { Stepped } \\
\text { roof } \\
\text { gardens- } \\
\text { surrounding } \\
\text { buildings }\end{array}$} & \multicolumn{2}{|c|}{$\begin{array}{c}\text { Local } \\
\text { plants } \\
\text { usage for } \\
\text { roof } \\
\text { gardens } \\
\text { creation }\end{array}$} & \multicolumn{2}{|c|}{$\begin{array}{c}\text { Use } \\
\text { simulation } \\
\text { software } \\
\text { during the } \\
\text { building } \\
\text { design }\end{array}$} \\
\hline 目 & & & & & & 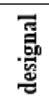 & 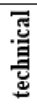 & ] & 胥 & 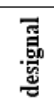 & 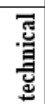 & 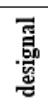 & 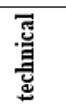 & 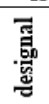 & 预 & 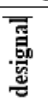 & 预 \\
\hline 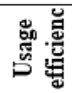 & $\checkmark$ & $\checkmark$ & $\checkmark$ & $\checkmark$ & & & & & & & & & & & & & \\
\hline 造 & & $\begin{array}{l}\mathrm{La} \\
\mathrm{Te} \\
\mathrm{be} \\
\text { lar }\end{array}$ & scap & elem & & & & & & & & & & & & & $\begin{array}{l}\text { oads, } \\
\text { d the }\end{array}$ \\
\hline
\end{tabular}

\section{Table 7 continued}

\begin{tabular}{|c|c|c|c|c|c|c|c|c|c|c|c|c|c|c|c|c|c|c|c|c|c|c|}
\hline \multicolumn{23}{|c|}{ Outer envelope } \\
\hline \multirow[b]{3}{*}{ 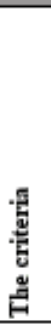 } & \multicolumn{19}{|c|}{ Energy conservation } & \multirow{2}{*}{\multicolumn{3}{|c|}{$\begin{array}{c}\text { Energy } \\
\text { generation }\end{array}$}} \\
\hline & \multicolumn{7}{|c|}{ Design elements } & \multicolumn{5}{|c|}{ Technical elements } & \multicolumn{7}{|c|}{ The used materials } & & & \\
\hline & 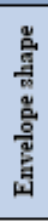 & 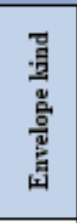 & 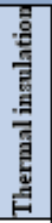 & 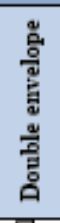 & 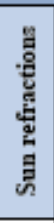 & 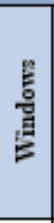 & ฐั้ & 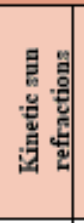 & 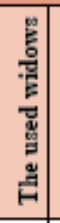 & 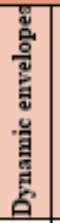 & 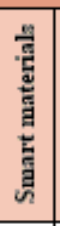 & 売 & 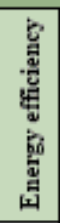 & 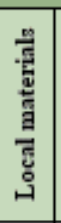 & 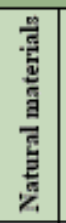 & 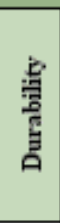 & 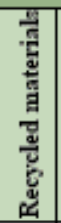 & 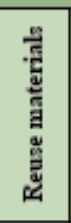 & పี & 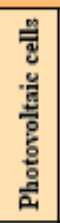 & 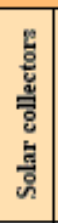 & 胥 \\
\hline 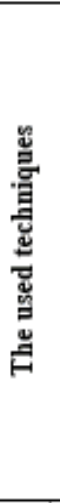 & & 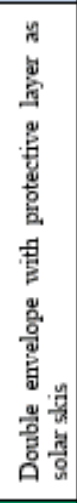 & 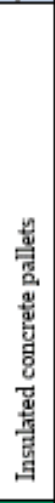 & 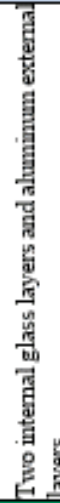 & 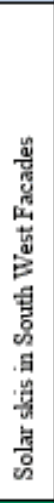 & 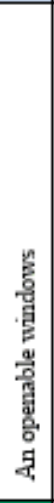 & & 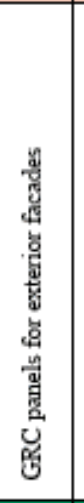 & 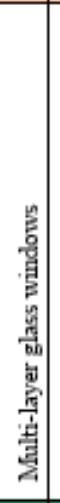 & 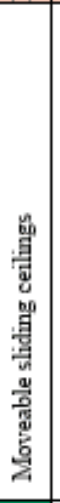 & & & 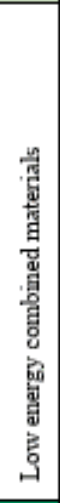 & 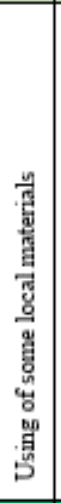 & 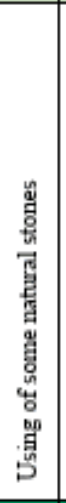 & 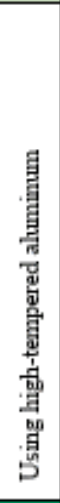 & 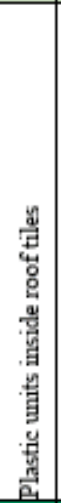 & 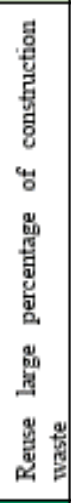 & & & & \\
\hline & & & & & & & & & & & & & & & & & & & & & & \\
\hline & & & & & & & & & & & & & & & & & & & & & & \\
\hline & & & & & & & & & & & & & & & & & & & & & & \\
\hline そ气 & $\bullet$ & $\begin{array}{l}\text { Insul } \\
\text { the ex } \\
\text { Struc } \\
\text { units, } \\
\text { Inter } \\
\text { with } \\
\text { fitted }\end{array}$ & $\begin{array}{l}\text { tur } \\
\text { suy } \\
\text { aal }\end{array}$ & $\begin{array}{l}\text { syst } \\
\text { orted } \\
\text { ourty }\end{array}$ & $\begin{array}{l}\text { em: } \\
\text { on } \mathrm{s} \\
\text { ard: }\end{array}$ & $\begin{array}{l}\text { Base } \\
x \text { me } \\
\text { cove }\end{array}$ & tal c & $\begin{array}{l}\text { inly on } \\
\text { olumns } \\
\text { with a } \\
\text { ists of }\end{array}$ & $\begin{array}{l}\text { oncre } \\
\text { evels } \\
\text { n a c } \\
\text { s up } \\
\text { mov } \\
9 \text { lig }\end{array}$ & $\begin{array}{l}\text { ete pa } \\
\text { of th } \\
\text { concr } \\
\text { to } 15 \\
\text { able } \\
\text { hting }\end{array}$ & $\begin{array}{l}\text { herm } \\
\text { rete } \\
\text { met } \\
\text { roof } \\
\text { ope }\end{array}$ & $\begin{array}{l}\text { al in } \\
\text { truct } \\
\text { ters h } \\
\text { syste } \\
\text { ning }\end{array}$ & $\begin{array}{l}\text { ure, } \\
\text { ligh } \\
\text { em w } \\
\text { s fro }\end{array}$ & $\begin{array}{l}\text { the in } \\
\text { nd sp } \\
\text { ith } 8 \text {. } \\
m \text { alu }\end{array}$ & $\begin{array}{l}\text { ans } \\
\text { pans } \\
4 \mathrm{~m}\end{array}$ & $\begin{array}{l}\mathrm{al} \mathrm{co} \\
8.4 \mathrm{~m} \\
* 16 \\
\mathrm{Am} \text { se }\end{array}$ & $\begin{array}{l}\text { ion } \mathrm{fr} \\
\text { urtya } \\
\text { eters } \\
8 \mathrm{~m} \text {, } \\
\text { gmer }\end{array}$ & $\begin{array}{l}\text { ons w } \\
\text { om so } \\
\text { rd cor } \\
\text { wide } \\
\text { consi } \\
\text { ats we }\end{array}$ & sts of & $\begin{array}{l}\text { used } \\
\text { adiat } \\
\text { witt } \\
\text { f } 8 \text { u }\end{array}$ & & \\
\hline
\end{tabular}




\subsection{Results and Discussion}

From the analytical study by comparing the case studies through the used techniques and design methods to rationalize the energy consumption, a set of results between these examples was drawn to achieve the energy rationalization criteria as follows, Table 8 .

Three ways of rationalizing energy consumption in buildings were concluded:

- First: Rationalize energy consumption: by reducing the demand energy "Reduce Loads" and then meet the needs efficiently "Meet Loads Efficiency" by using modern technologies in different building's elements (external elementsouter envelope-internal elements) to achieve the required function efficiently.

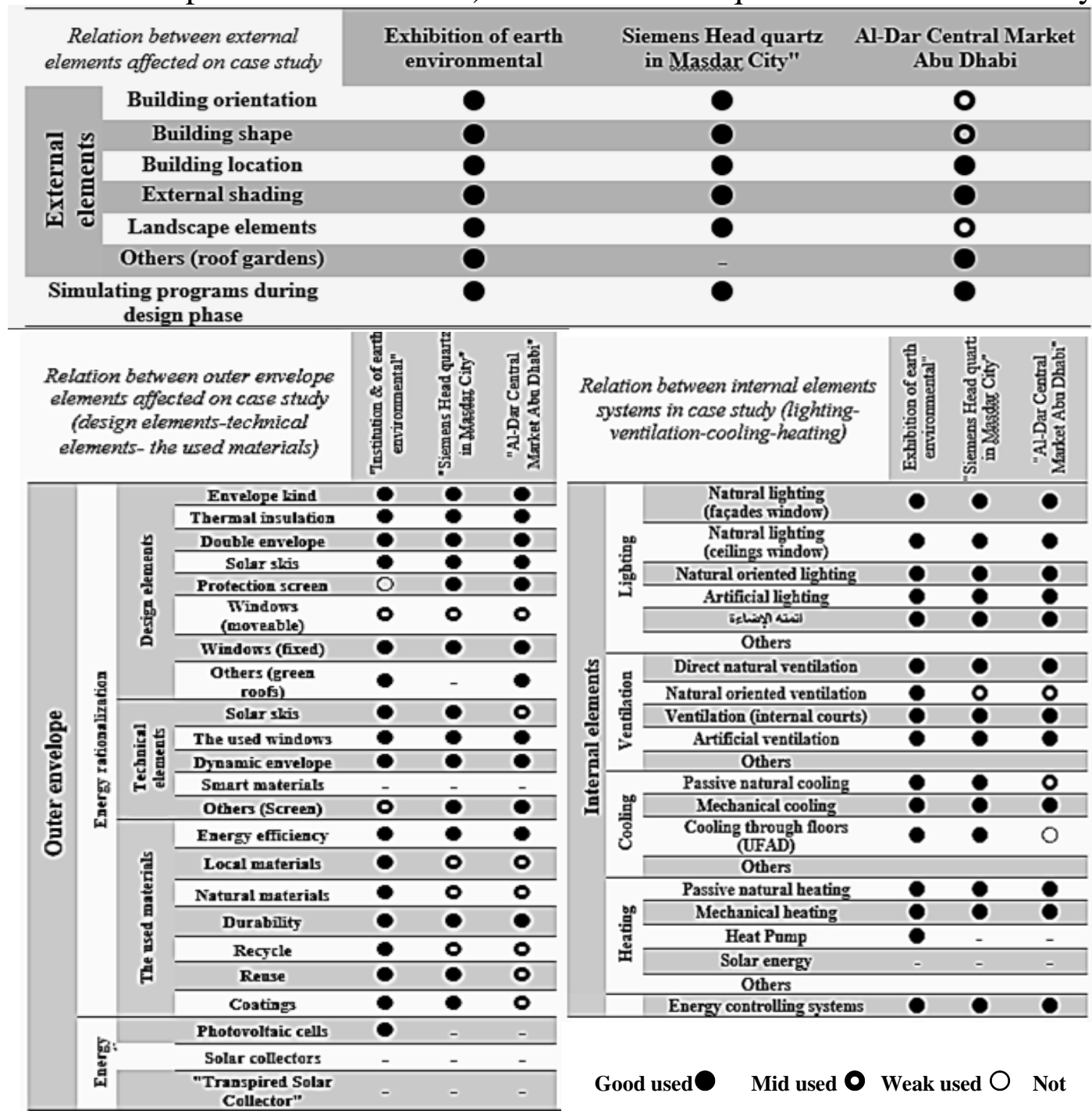

Table 8 Analysis of the used techniques in the case study examples [Author]

- Second: Energy generation from renewable sources: by integrating the energy generation systems in the building's outer envelope by installation in external façades and ceilings, to help in providing the needed energy for operation, some of them reach to self-sufficiency. 
- Third: Energy control and management systems: that assist to reduce the lost energy even with using high-efficiency equipment, even with the misuse of services equipment and systems as lighting, ventilation, cooling, and heating.

From the above theoretical and analytical study, it was possible to develop a methodology to rationalize energy consumption in buildings during its life cycle, Fig 15.

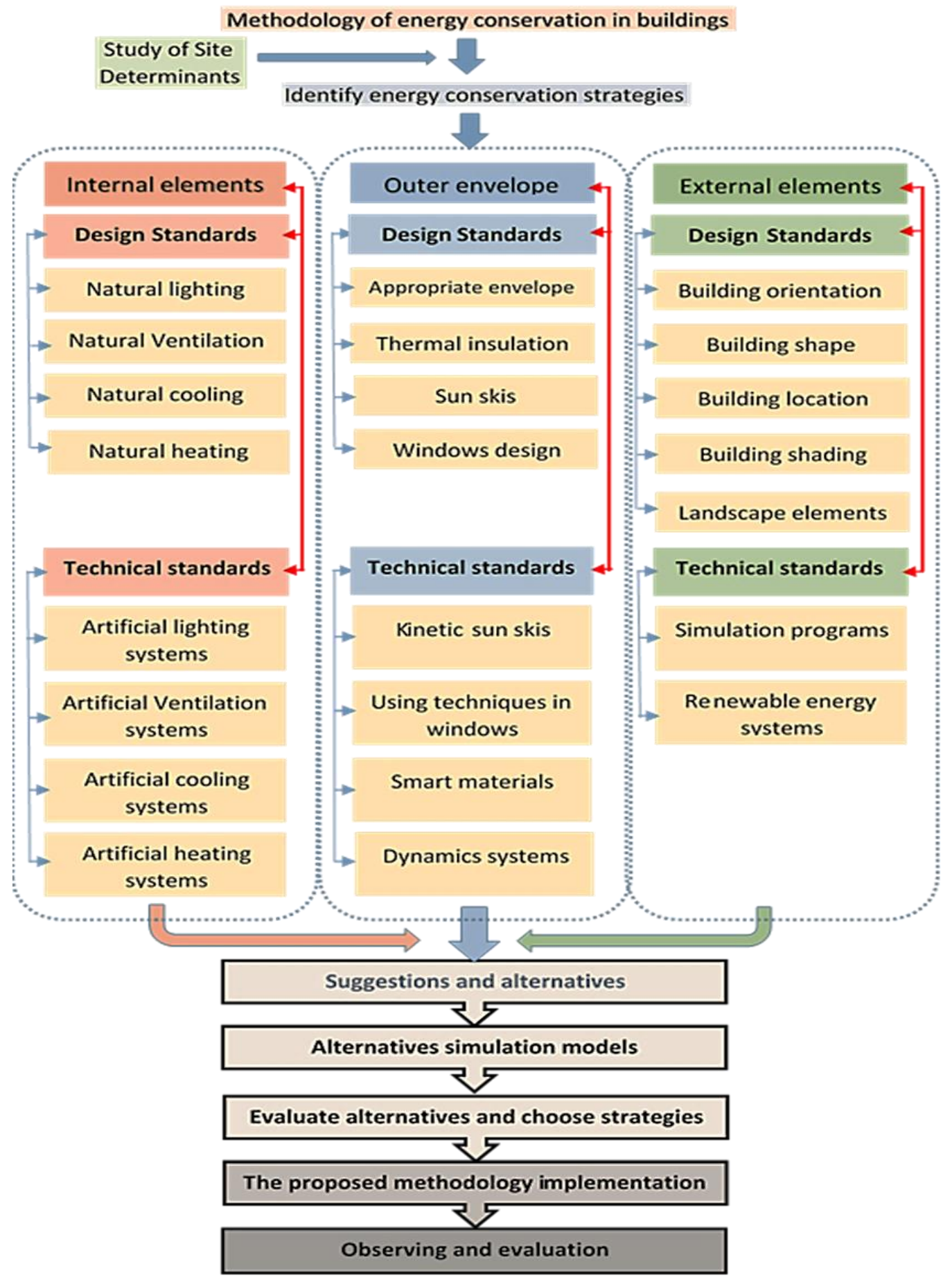

Figure 15 The proposed methodology for energy rationalization in buildings [Author] 


\section{Conclusion and Recommendation}

As a result, from the theoretical and analytical study in rationalizing energy consumption in buildings, some points were concluded followed by some recommendations.

\subsection{Conclusion}

- Rationalization of energy consumption means the optimal consumption of energy resources, to limit their waste without compromising the user's comfort, productivity or affect the used equipment efficiency.

- Energy conservation fields in the building and the improving the user's efficiency were determined by the following rationalization methods:

- Associated with the used equipment, tools, and devices

- Related to the used energy-consuming systems in the building.

- Connected with the building itself and the surrounding elements.

- Combined with the outer envelope design.

- Related to the person who uses the building.

- The modern technologies used to rationalize the energy were applied on three elements (external elements - outer envelope- internal elements).

- Rationalization strategies for electricity consumption are based on several fields begins with reducing consumption by applying design criteria, next use modern technologies efficiently and then integrate renewable energy generation systems.

- Buildings that succeeded in achieving good levels of ventilation, cooling and heating relies on the negative design, using modern technologies with high-efficiency systems, and building control systems to reduce cooling, heating loses and total control of its loads.

- The most common systems that used in energy generation are photovoltaic cells with various types, including chips united in glass facades, their location varies in the buildings either in the front facades or in flat and tilted ceilings.

- A methodology was set up to use modern technologies in the various building elements to contribute in rationalizing building's energy consumption and increase efficiency during its life cycle.

\subsection{Recommendations}

- The proposed methodology of the rationalization building energy consumption should be applied to the new projects during the design process.

- The need to formulate a scientific mechanism to evaluate the alternatives and selecting the strategies from the proposed methodology, by converting the used technology's standards for rationalizing energy consumption to a digital scale, that can be applied in different buildings during the design and operation stages.

- Designers in different fields should integrate the building energy management systems to control the operation of electrical appliance, cooling systems, heating, lighting and manage renewable energy systems.

- Architects should study and analyze the global experiences that concern in energy saving mechanisms for existing or new architectural projects to benefit from them in the case of Egypt. 
- The importance of holding seminars for architects and architecture students to warn them about the expected environmental dangers and to strengthen the rationalization concept.

- The need to organize awareness campaigns in the visual and audiovisual channels carried out by the Ministries of Information and Culture and directed to different society sectors about the importance of rationalizing energy consumption in buildings.

- The State must put the time plan rules to replace the used lighting, ventilation, cooling systems and appliances in low-efficiency with better efficiency ones, which are based on the latest technologies in this field, without compromising the required performance level.

- Encouraging the public and residential buildings owners to integrate renewable energy generation systems, especially in remote areas, by providing technical support and longterm financing loans.

- The consultants should subject the buildings at the licensing stage to energy analysis and simulation programs.

\section{References}

1. UNEP, "Building and climate change: status, challenges, and opportunities", United Nations Environmental Program, 2007.

2. Ibrahim El Ghitani, Amani Abdel Ghani, "The Prospects of Renewable Energy in Egypt: Opportunities to Get Out of the Specter of Energy Downturn", Egyptian Center for Studies and Information, Cairo, 2012, Site: ascicenter, org.

3. Renewable Energy Authority, Renewable Energy in Egypt, Annual Report, Cairo, 2011

4. http://renewableenergydev.com/benefits-of-solar-energy/, (3-8-2016).

5. Solar thermal power plants, Renewable Energy World 06/2003 pp. 109$\mathrm{ttp}: / / \mathrm{www}$. volker-quaschning.de/articles/fundamentals2/, (1-8-2016).

6. Dave Parker, Micro generation, "Low energy strategies for larger buildings", Elsevier Ltd, oxford, 2009

7. Saud Yousef Ayash, "Alternative Energy Technology", Knowledge World, Volume 38, National Council for Culture, Arts and Letters, Kuwait, 1981.

8. Ehab Mahmoud Okbba, "Approaches to Environmental Design Towards Compatibility with Natural Environment Changes", Tawfiq Al Amara and Urbanization Conference in Transformations Contracts, Cairo University, Cairo, 2006

9. Aktham Mohamed Abul-Ela, Kamilia Youssef, "Electricity Efficiency: Objectives, Responsibilities and Procedures", Committee on Rationalization, Ministry of Electricity and Energy, Cairo, 2013.

10. Energy Conservation and Environmental Protection Project - Prepared by Hagerlebays Consulting, Companies Energy Management, 1996

11. Mohamed Baradab, "Energy Efficiency and Efficiency Improvement in Building Sector in ESCWA Countries", UN Committee,"The Third Scientific Symposium of the 22nd Arab Engineering Conference for Energy and its Sources in the Arab World and Sustainable Development", Damascus, 2000.

12. American Institute of Architects, "The Carbon Neutral Design Project", 2012, site:http://www.tboake.com/carbon-aia, accessed 1-8-2016.

13. https://www.aud.ucla.edu/heed, Accessed 01-03-2016. 
14. Christian Schittich, "In Detail: Building Skins, new enlarged edition”, Birkhauser publisher for Architecture, Berlin, 2006,

15. Urukia Magazine, Adaptable facade with hexagonal parametric pattern for "Chameleon" mixed-use office, Online site:http://www.urukia.com/adaptable-facade-hexagonalparametric-pattern-for-chameleon-mixed-use-office/ Accessed 1-2-2016

16. Manfred Hegger, Mattias Fuchs, Others, "Energy Manual Sustainable architecture", Birkhauser, Berlins, 2008

17. Norbert Lechner, "Heating, Cooling, Lighting: Sustainable Design Methods for Architects", John Wiley \&sons. USA, 2015,

18. Jin Kim \& Rigdon, B, "Sustainable Architecture module: Qualities, Use, and Examples of Sustainable building Materials", 1998, site:http:// www.umich.edu/ nppcpub/ accessed 3-9-2016.

19. Nico Saieh, "California Academy of Sciences", 2008, site http://www.archdaily.com/ 6810 /California-academy-of-sciences-Renzo-piano/, (17-11-2016).

20. David Basulto, "California Academy of Science / Green roof construction and opening", 2008, site: http://www.archdaily.com/7033/california-academy-of-science-green-Roofconstruction-and-opening/, (15-11-2016)

21. ArchDaily, "Siemens HQ in Masdar City / Sheppard Robson ", 2014, http://www.archdaily.com/539213/siemens-hq-in-masdar-city-sheppard-robson/, (01-122015).

22. Zumtobel, "Siemens Headquarters Masdar City", Report Available on: Dubai.Zumtobel.com, Accessed 01-12-2015.

23. Stu Robarts, "The roof of Abu Dhabi Central Market can now be closed to keep it cool", 2014, site http://newatlas.com/abu-dhabi-central-market/34387/, (1/11/2015).

24. Gabriela Celani, David Moreno Sperling, "Computer-Aided Architectural Design Futures: The Next City - New Technologies and the Future of the Built Environment", 16th International Conference, CAAD Futures 2015, São Paulo, Brazil, July 8-10, P.180181.

\section{التطبيق المنهجي للتقنيات الحديثة لترشيد استهلاك الطاقة في المباني}

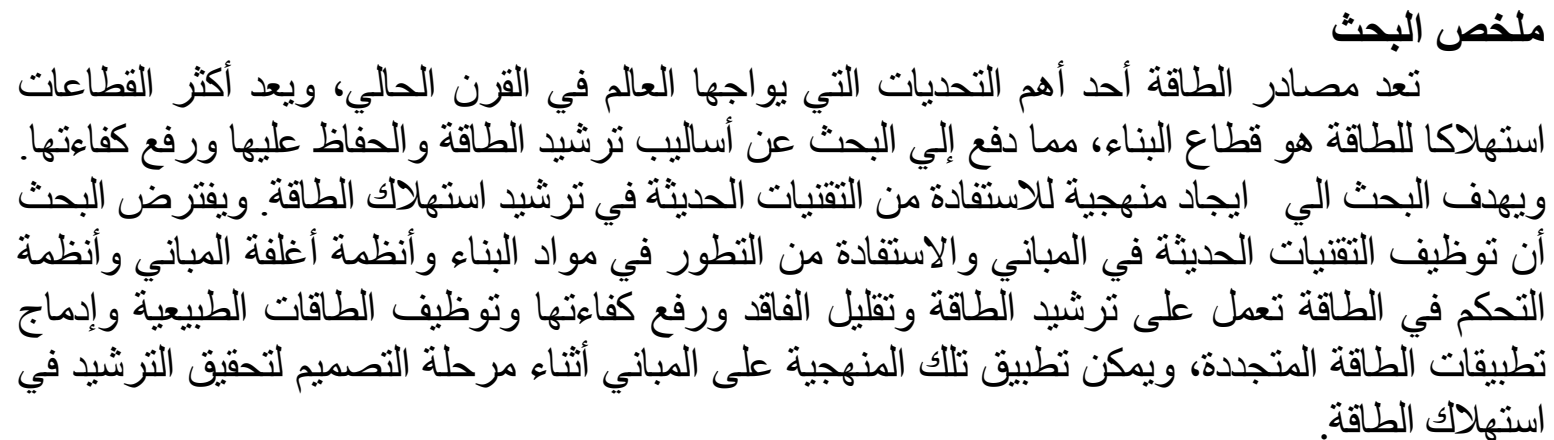

